$1-1-2019$

\title{
Explaining Choice-of-Entity Decisions by Silicon Valley Start-Ups
}

\author{
Gregg Polsky \\ Francis Shackelford Distinguished Professor in Taxation Law University of Georgia School of Law, \\ gregg.polsky@uga.edu
}

University of Georgia School of Law

Research Paper Series

Paper No. 2018-11

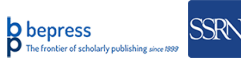

\section{Repository Citation}

Gregg Polsky, Explaining Choice-of-Entity Decisions by Silicon Valley Start-Ups, 70 Hastings L.J. 409 (2019),

Available at: https://digitalcommons.law.uga.edu/fac_artchop/1273

This Article is brought to you for free and open access by the Faculty Scholarship at Digital Commons @ University of Georgia School of Law. It has been accepted for inclusion in Scholarly Works by an authorized administrator of Digital Commons @ University of Georgia School of Law. Please share how you have benefited from this access For more information, please contact tstriepe@uga.edu. 


\title{
Explaining Choice-of-Entity Decisions by Silicon Valley Start-Ups
}

\author{
GREGG POLSKY ${ }^{\dagger}$
}

Perhaps the most fundamental role of a business lawyer is to recommend the optimal entity choice for nascent business enterprises. Nevertheless, even in 2018, the choice-of-entity analysis remains highly muddled. Most business lawyers across the United States consistently recommend flow-through entities, such as limited liability companies and $S$ corporations, to their clients. In contrast, a discrete group of highly sophisticated business lawyers, those who advise start-ups in Silicon Valley and other hotbeds of start-up activity, prefer C corporations.

Prior commentary has described and tried to explain this paradox without finding an adequate explanation. These commentators have noted a host of superficially plausible explanations, all of which they ultimately conclude are not wholly persuasive. The puzzle therefore remains.

This Article attempts to finally solve the puzzle by examining two factors that have been either vastly underappreciated or completely ignored in the existing literature. First, while previous commentators have briefly noted that flow-through structures are more complex and administratively burdensome, they did not fully appreciate the source, nature, and extent of these problems. In the unique start-up context, the complications of flow-through structures are exponentially more problematic, to the point where widespread adoption of flow-through entities is completely impractical. Second, the literature has not appreciated the effect of perplexing, yet pervasive, tax asset valuation problems in the public company context. The conventional wisdom is that tax assets are ignored or severely undervalued in public company stock valuations. In theory, the most significant benefit of flow-through status for start-ups is that it can result in the creation of valuable tax assets upon exit. However, the conventional wisdom makes this moot when the exit is through an initial public offering or sale to a public company, which are the desired types of exits for start-ups. The result is that the most significant benefit of using a flow-through is eliminated because of the tax asset pricing problem. Accordingly, while the costs of flow-through structures are far higher than have been appreciated, the benefits of these structures are much smaller than they appear.

$\dagger$ Francis Shackelford Distinguished Professor in Taxation Law, University of Georgia School of Law. Thanks to Brad Bernthal, Brian Broughman, Jason Breen, Omri Marian, Usha Rodrigues, Gladriel Shobe, and Larry Zelenak for comments on earlier drafts and to Robert Daily for research assistance. 


\section{TABLE OF CONTENTS}

INTRODUCTION

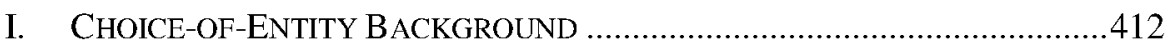

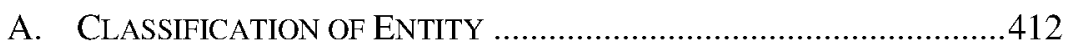

B. FUNDAMENTAL TAX DIFFERENCES ………...............................413

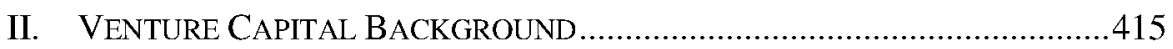

A. MAIN STREET NEW BUSINESSES.................................................

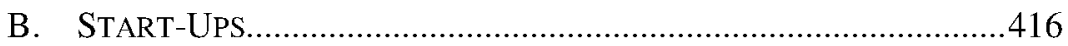

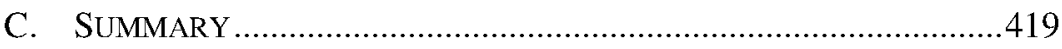

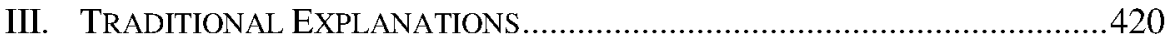

A. THE PRESENCE OF TAX-INDIFFERENT OWNERSHIP.......................421

B. WHERE ARE THE TAXABLE INVESTORS? ...................................422

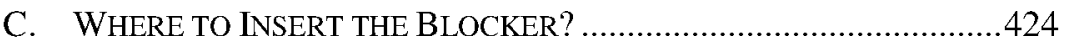

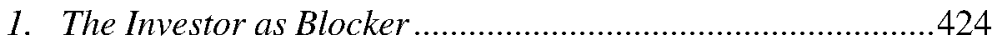

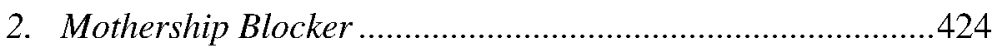

3. Separate Blockers for Each Start-Up …..................................425

4. The Start-Up as Blocker .......................................................427

D. TREATMENT OF THE UNBLOCKED INVESTORS .............................428

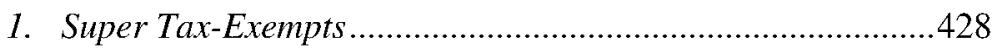

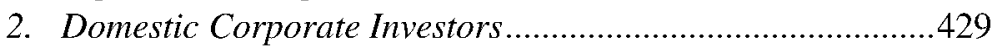

3. Individual U.S. Investors .......................................................430

4. Summary of Tax Benefits from LLC Versus Corporate

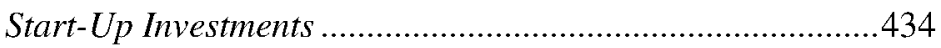

E. OTHER IDENTIFIED FACTORS SUPPORTING THE CORPORATE

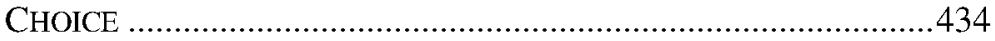

IV. UNDERAPPRECIATED FACTORS ENCOURAGING CORPORATE

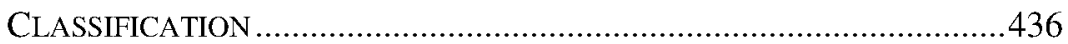

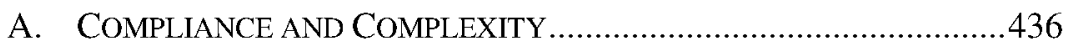

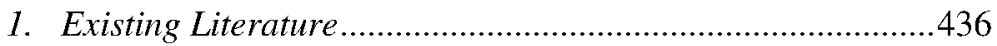

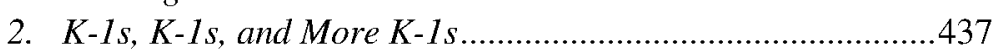

3. The Nature of Early Stage Start- $U$ p Investing........................440

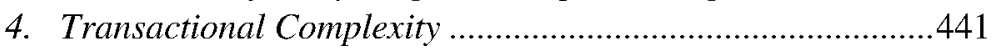

5. Ex Ante Picking and Choosing ..............................................444

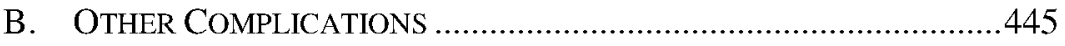

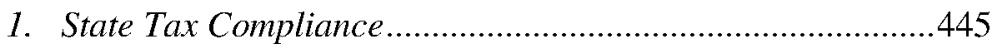

2. Equity Compensation Design ................................................446

C. Practical Difficulties IN FETChing THE SUB Premium........446

1. The Theoretical Advantage of Delivering a SUB ..................447

2. Discussion of SUB Delivery in the Existing Literature ..........450

3. Delivery of the SUB in Practice ............................................450

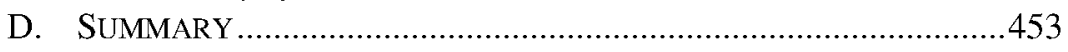




\section{INTRODUCTION}

Perhaps the most fundamental role of the business lawyer is to recommend the optimal entity choice for nascent business enterprises. Nevertheless, even in 2018, the choice-of-entity analysis remains highly muddled. Most advisors across the United States consistently recommend flow-through entities, such as limited liability companies and $\mathrm{S}$ corporations to their clients. In contrast, a discrete group of highly sophisticated lawyers, those who advise start-ups in Silicon Valley and other hotbeds of start-up activity, stubbornly prefer C corporations.

Prior commentary has described and tried to explain this paradox without finding an adequate explanation. ${ }^{1}$ These commentators have noted a host of superficially plausible explanations, all of which, they ultimately conclude, are not wholly persuasive. The puzzle therefore remains.

This Article attempts to finally solve the puzzle by examining two factors that have been either vastly underappreciated or completely ignored in the existing literature. First, while previous commentators have briefly noted that flow-through structures are more complex and administratively burdensome, they did not fully appreciate the source, nature, and extent of these problems. In the unique start-up context, the complications of flow-through structures are exponentially more problematic, to the point where widespread adoption of flow-through entities is completely impractical. Second, the literature has not appreciated the effect of perplexing, yet pervasive, tax asset valuation problems in the public company context. The conventional wisdom is that tax assets are ignored or severely undervalued in public company stock valuations. ${ }^{2}$ In theory, the most significant theoretical benefit of flow-through status for start-ups is that it can result in the creation of valuable tax assets upon exit. However, the conventional wisdom makes this moot when the exit is through an initial public offering or sale to a public company, which are the desired types of exits for start-ups. The result is that the most significant benefit of using a flow-through is eliminated because of the tax asset pricing problem. Accordingly, while the costs of flow-through structures are far higher than have been appreciated, the benefits of these structures are much smaller than they appear.

Part I of this Article provides background on the choice-of-entity issue and describes the tax implications of the choice. Part II discusses how Silicon Valley

1. See generally Joseph Bankman, The Structure of Silicon Valley Start-Ups, 41 UCLA L. REV. 1737 (1994); Victor Fleischer, The Rational Exuberance of Structuring Venture Capital Start-ups, 57 TAX L. Rev. 137 (2003); Daniel S. Goldberg, Choice of Entity for a Venture Capital Start-Up: The Myth of Incorporation, 55 Tax Law. 923 (2002); Calvin H. Johnson, Why Do Venture Capital Funds Burn Research and Development Deductions?, 29 VA. TAX REV. 29 (2009).

2. See Gregg Polsky \& Adam H. Rosenzweig, The Up-C Revolution, 71 TAX L. Rev. 415, 429-32 (2018) (explaining the conventional view that tax assets are undervalued in the public company context). 
start-ups differ from other small businesses, as the solution to the puzzle must be based on one or more of these differences. Part III sets forth the traditional, yet not wholly satisfying, explanations for why Silicon Valley start-ups prefer corporations. Part IV explains the underappreciated factors that push the choiceof-entity equation toward the corporate form. The Article then concludes by explaining how recent developments will affect the choice-of-entity analysis going forward.

\section{CHOICE-OF-ENTITY BACKGROUND}

\section{A. Classification of ENTITY}

Owners of a new business can choose among a variety of state law entities. A business can be operated as a corporation, a general partnership, a limited partnership, a limited liability company (LLC), a limited liability partnership (LLP), a limited liability limited partnership (LLLP), or another alphabet soup entity, depending on the laws in the state of organization. In most situations, the corporate or LLC forms will be the most attractive because they are universally available to all sorts of businesses and offer complete limited liability for all of their owners. ${ }^{3}$

From a federal income tax perspective, there are only two main types of "tax entities:" flow-through and corporate. S corporations and partnerships are flow-through entities, while $\mathrm{C}$ corporations are corporate entities. Between the two types of flow-through entities, partnerships are generally more attractive. In part, this is because $\mathrm{S}$ corporation status is available only for entities that are owned entirely by U.S. individuals (as opposed to owners that are entities themselves or who are foreign individuals) ${ }^{4}$ Accordingly, this Article will focus on partnerships as the flow-through entity of choice, but the analysis would not change significantly if the flow-through entity were an $\mathrm{S}$ corporation.

Tax partnerships generally include all state law entities other than corporations. ${ }^{5}$ Thus, general and limited partnerships, LLCs, LLPs, and LLLPs are all partnerships for tax purposes. ${ }^{6} \mathrm{C}$ corporations include state law corporations and other business entities that affirmatively elect corporate status. ${ }^{7}$ Typically, a new business will often need to choose between being a state-law LLC taxed as a partnership or a state-law corporation taxed as a C corporation. The state law consequences of each are nearly identical, but the tax distinctions are vast. ${ }^{8}$

3. Goldberg, supra note 1, at 923. LLPs and LLLPs are less popular because they generally offer less limited liability protection than corporations or LLCs.

4. See I.R.C. \$1361(b)(1) (2012).

5. See generally Treas. Reg. $\$ 301.7701-3(2006)$.

6. Treas. Reg. § 301.7701-3(b) (2006)

7. Id.

8. Jack S. Levin \& Donald E. Rocap, Structuring Venture Capital, Private Equity, and Entrepreneurial Transactions ITt 303.1.1-303.1.4, at 3-52 to 3-54 (Martin D. Ginsburg \& Russell S. Light 


\section{B. FundAMENTAL TAX DIFFERENCES}

Unlike corporations, partnerships themselves are not subject to tax. ${ }^{9}$ Instead, all of the partnership's taxable income (or loss) flows through the entity and is reported on the partners' individual tax returns, in the same manner as if each partner had realized its share of the partnership income (or loss) directly. ${ }^{10}$ This results in partnership income being taxed once and only once, when the income is earned by the partnership. ${ }^{11}$ When that income is subsequently distributed (in the form of cash or property distributions), those distributions are generally tax-free so that there is no second level of tax. ${ }^{12}$ If a partnership generates tax losses, those losses also flow through the entity and are available to the partners to offset income from other sources, subject to certain general restrictions and limitations that may apply to loss utilization. ${ }^{13}$

On the other hand, a $\mathrm{C}$ corporation is taxed separately as an entity. ${ }^{14}$ The corporation realizes income and pays tax on that income much like an individual would, albeit now at the dramatically reduced tax rate of $21 \%$, down from the historical $35 \%$ rate.$^{15}$ When the corporation subsequently distributes its after-tax income in the form of a dividend, the shareholders generally pay a second level of tax. ${ }^{16}$ The dividend tax rate is lower than the ordinary individual tax rate by approximately twenty percentage points. ${ }^{17}$ This reduction blunts the effect of double taxation, but nevertheless the double taxation has still historically resulted in much harsher taxation of income than if the income were earned directly, or through a partnership, and taxed only once. ${ }^{18}$

eds., 2014) (discussing the similarities and distinctions between the traditional corporate form and the newer LLC form, especially in regards to legal liabilities).

9. I.R.C. $\$ 701(2012)$.

10. Id. $\S 702$.

11. LEVIN \& ROCAP, supra note 8 , II 302.2.1, at 3-34.

12. I.R.C. $\$ 731$

13. Individual partners face three separate limitations that may impact their ability to tax losses: (1) if they do not have enough passive income, $i d . \$ 469$; (2) if the partners do not have enough amounts at risk in their partnership, id. $\S 465$; or (3) if the partners do not have enough outside basis in their partnership interest, $i d$. $\S 704(\mathrm{~d})$.

14. Id. $\$ 11(\mathrm{a})$

15. James R. Browne, Choice of Entity for a Startup Business After Tax Reform, NAT'L L. REv. (Aug. 30, 2018), https://www.natlawreview.com/article/choice-entity-startup-business-after-tax-reform ("A corporation is a separately taxable entity and pays tax on its taxable income at a flat rate of $21 \%$, down from graduated rates of up to $35 \%$ for 2017 and prior years.").

16. I.R.C. $\S 61(a)(7)$. The same double taxation results if the corporation reinvests (instead of distributes) its after-tax cash. The reinvestment increases the stock price. When the shareholder sells the stock, that incremental increase will be taxed as additional capital gain.

17. Id. $\S 1$.

18. For example, assume that $\$ 100$ is earned by a corporation. Historically, the corporation would pay $\$ 35$ of tax, leaving $\$ 65$ to be distributed. A $20 \%$ tax on a dividend of $\$ 65$ would leave the shareholder with $\$ 52$, meaning that the combined tax rate was $48 \%$. On the other hand, if the $\$ 100$ was earned by a partnership and the partners were subject to a $40 \%$ ordinary income tax rate, the partners would be left with $\$ 60$. Other factors, such as state taxes and the net investment income tax in $\S 1411$, complicate this analysis, but in general, income earned by corporations was historically subject to greater taxation than income earned by a partnership. The Tax Cuts and Jobs Act of 2017, by significantly reducing the corporate tax rate from $35 \%$ to $21 \%$, reduces this 
If the corporation generates net operating losses (NOLs), those losses are trapped in the corporation. ${ }^{19}$ NOLs can generally be carried forward and used to offset future income realized by the corporation. ${ }^{20}$ Delayed utilization of losses reduces their value due to the time-value of money. In addition, NOLs that are never used, because the corporation never has sufficient income against which to apply them, result in no tax benefit whatsoever.

The single-versus-double tax and the untrapped-versus-trapped loss distinctions are the most fundamental differences between partnerships and corporations. Another important distinction between the two entities relates to flexibility. If the owners of a business entity that is classified as a partnership later desire to reclassify the entity as a corporation, the conversion typically generates no tax costs. ${ }^{21}$ On the other hand, reclassifying a corporation as a partnership requires an actual or deemed liquidation of the corporation, which will have significant tax costs if the business has appreciated in valuation substantially between its inception and the date of conversion. ${ }^{22}$ These costs often make a conversion from corporation to partnership financially infeasible. ${ }^{23}$

For these three primary reasons (reduced taxation of income, treatment of losses, and flexibility), business lawyers generally recommend forming a partnership over a corporation when advising early stage businesses. ${ }^{24}$ Other factors may play a role, but they too tend to push in favor of partnership classification. For example, property can generally be easily moved into and out of partnerships without tax consequences, which is not the case in the corporate context. ${ }^{25}$ Nevertheless, in some circumstances, corporate status (whether $\mathrm{C}$ or

disparity and in some cases, turns it on its head. Tax Cuts and Jobs Act of 2017, Pub L. No. 115-97, 131 Stat. 2054.

19. Bankman, supra note 1, at $\mathbf{1 7 5 3}$ ("Losses from the partnership would flow through to the partners and could be used by those partners to offset other sources of income, while losses from the corporation remain 'trapped' at the corporate level.").

20. I.R.C. $\$ 172$.

21. Joseph W. Bartlett, Equity Finance: Venture Capital, Buyouts, Restructurings, and REORGANIZATIONS $\$ 3.5 \mathrm{~A}$ (2d ed. Supp. 2018) (" [U]sually little or no tax gain need be recognized when an entity that is classified as a partnership for federal tax purposes merges into another entity that is classified as a partnership for federal tax purposes or converts into or merges with a corporation and the $80 \%$ 'control' test of I.R.C. $\$ \$ 351$ (a) and 368 (c) is satisfied.").

22. I.R.C. $\$ 336$ (a) (requiring the recognition of gain by liquidating corporation to the extent the corporation's assets have a fair market value in excess of basis).

23. John O. Everett et al., Planning Considerations When Converting a C Corporation to an LLC, TAX ADVISER (Jan. 31, 2011), https:/www.thetaxadviser.com/issues/2011/feb/raabe-banner-feb11.html (noting that if the converting corporation holds highly appreciated assets, there could be "significant and immediate income (and transfer) tax costs").

24. See, e.g., Browne, supra note 15 ("A good starting point for the analysis is to abandon the reflexive choice of a corporation and view the LLC as the default legal entity choice.").

25. See Laurence E. Crouch, Revival of the Choice of Entity Analysis: Use of Limited Liability Companies for Start-Up Businesses and the "Up-C" Structure, in 11 The PARTNERSHIP TAX PRACTICE SERIES: PlanNING FOR DOMESTIC AND FOREIGN PARTNERSHIPS, LLCS, JOINT Ventures \& OTHER STRATEGiC AllianCES $210-17$ (Louis S. Freeman \& Clifford M. Warren eds., 2017) ("It is easier for an LLC than a corporation to acquire these types of entities on a tax-free basis in exchange for its equity. This is because a tax-free reorganization would 
S) may be preferred. For example, many professional service businesses (for example, law firms and medical practices) are structured as $\mathbf{S}$ corporations to exploit an employment tax advantage. ${ }^{26}$ But, in general, new businesses across the United States are advised to organize themselves as LLCs, which are taxed as partnerships. ${ }^{27}$

However, this conventional wisdom has been disregarded in the venture capital (VC) world. In Silicon Valley and other hotbeds of VC activities, founders are often told in no uncertain terms to form a corporation. ${ }^{28}$ And, if the business was originally formed as a partnership, $\mathrm{VC}$ investors will typically require that it convert to corporate status as a condition of their investment. ${ }^{29}$ The conventional choice-of-entity approach is thus completely flipped on its head in the VC world. This is the puzzle that is explored in this Article.

\section{VENTURE CAPITAL BACKGROUND}

Early stage businesses that desire VC investment ("start-ups") are distinct from other nascent businesses ("Main Street new businesses") in a variety of ways. The explanation for the choice-of-entity puzzle therefore must be based on one or more of these differences. This Part describes the material differences.

Of course, not all start-ups are alike; nor are all new small businesses. And, occasionally there is some crossover between the two. For example, a Main Street small business may not initially plan to solicit VC funding, but may, due to higher-than-expected growth potential, become a start-up. Nevertheless, the differences described below are generally representative of the two mostly distinct worlds.

\section{A. Main STREet New BusinesSES}

Main Street new businesses typically obtain financing from just a few sources. Besides using their own capital and those of friends and family, ${ }^{30}$ small businesses often look to debt financing from banks or the Small Business Administration. ${ }^{31}$ Importantly, the equity investors are U.S. individuals who are

not be available if the target is not a corporation and because section 721 , unlike section 351 , does not require the persons receiving interests in the acquiring entity to be in control of such acquiring entity.").

26. There are certain employment tax benefits associated with S-Corps and not associated with LLCs or partnerships. See Thomas E. Fritz, Flowthrough Entities and the Self-Employment Tax: Is It Time for a Uniform Standard, 17 VA. TAX REv. 811, 833-34 (1998).

27. See Browne, supra note 15.

28. See Bankman, supra note 1, at 1739-40 (noting that at the time of VC investment, VC funds will structure, or re-structure, entities to corporate form).

29. Id.

30. See How to Borrow from Family and Friends, WALL St. J.: How to GuDE, http://guides.wsj.com/small-business/funding/how-to-borrow-from-family-and-friends/ (last visited Jan. 19, 2019) (noting that founders usually resort to informal investors such as family and friends).

31. Jared Hecht, Are You Ruming a Startup or Small Business? What's the Difference?, Forbes (Dec. 8, 2017, 2:39 PM), https://www.forbes.com/sites/jaredhecht/2017/12/08/are-you-running-a-startup-or-smallbusiness-whats-the-difference/\#46d4e3b226c5 ("[S]mall business owners typically turn to debt financing through small business loans to meet their funding goals."); see also Rosemary Peavler, Commercial Bank Loans 
not "professional" start-up investors. In addition, there usually are only a handful of initial equity owners.

These new businesses, while riskier than existing small businesses, are intended to be operated for a long time and, if all goes well, to be carried on by future generations of the founders. ${ }^{32}$ The upside is often quite limited. There is typically no hope or inclination for the business to eventually go public or be sold to a large company. ${ }^{33}$ Instead, the desire is to slowly and steadily build and grow an increasingly profitable business that will support the founders and their families. ${ }^{34}$ In addition, the growth is often expected to be funded internally, by retained earnings or new debt that is supported by expected future growth, as opposed to new sources of equity capital. ${ }^{35}$

Main Street new businesses generally do not pay equity compensation to a large number of service providers. ${ }^{36}$ Thus, the founders get all or nearly all of the sweat equity. Additional service providers are commonly compensated with salaries and, perhaps, incentive-based bonuses, but not with equity. ${ }^{37}$ This factor, combined with the small number of initial cash investors and absence of followon investors, means that there is often only a handful of equity owners.

Finally, the expectation for the founders is that the small business will fairly quickly become a profitable enterprise. ${ }^{38}$ Founders may expect some losses in the early years, but those losses will not be extreme and the hope is that, at least within the first few years, the business is in the black. ${ }^{39}$

\section{B. START-UPS}

In the start-up context, VC funds supply a large amount of the equity investments. ${ }^{40} \mathrm{VC}$ funds themselves are owned mostly by professional VC investors, such as charities and private foundations, pension funds, sovereign wealth funds, family offices, and wealthy individuals. ${ }^{41}$ In addition, angel investors (wealthy individuals who invest directly in a large number of very

for Small Businesses, BALANCE SMALL BuS. (May 15, 2018), https://www.thebalancesmb.com/business-loansfrom-commercial-banks-for-small-businesses-393101 (describing commercial bank loans as an important source of money for small businesses); U.S. SMALL BUS. ADMIN., https:/www.sba.gov/funding-programs/loans (last visited Jan. 19, 2019) (noting that the SBA helps provide loans to small businesses).

32. See Hecht, supra note 31 ("[G]enerally speaking, small business owners intend to create self-sustaining and long-lasting small businesses.").

33. See id.

34. See id. ("[T] he end goal for a small business ... [is] to stay in business.").

35. See id. (noting that the goal for small businesses is to become "self-sustaining").

36. Cf. Johnson, supra note 1, at 69-71 (discussing the use of stock option (or equity) compensation for start-ups).

37. Id.

38. See Hecht, supra note 31 ("A small business [unlike a startup] is a self-sustaining organization that generates revenue from the first day of opening. They don't require major investments and time to formulate a company that works.").

39. See id.

40. Susan C. Morse \& Eric J. Allen, Innovation and Taxation at Start-up Firms, 69 TAX L. REV. 357, 374 (2016) (discussing which start-ups try to obtain funding from VC funds).

41. LEVIN \& ROCAP, supra note 8, TI 102, at 1-3. 
early-stage start-ups) along with founders and their friends and family, often make seed equity investments before, or occasionally simultaneously with, VC investors. ${ }^{42}$

VC funds look exclusively for high-risk, high-reward investments. ${ }^{43}$ They invest in highly speculative business ideas with extremely significant opportunities for growth, but also with a very high likelihood of failure. ${ }^{44}$ Because VC funds generally are required to liquidate within about ten years, VC funds have extremely short time horizons. ${ }^{45}$ They seek quick exits, generally within three to seven years of initial investment. ${ }^{46}$ The ideal exits are IPOs or sales to public companies. ${ }^{47}$

VC funding comes in stages. ${ }^{48}$ The expectation is that the start-up, if it continues to be a worthwhile VC prospect, will require numerous rounds of investment before it can successfully be exited. ${ }^{49}$ Future rounds can be funded by participants in previous rounds (in the form of follow-on investments) or by new VC backers. ${ }^{50}$ Each round often involves the participation of multiple VC funds. ${ }^{51}$

Start-ups typically issue large amounts of incentive compensation, either in the form of outright equity, such as restricted stock, or options. ${ }^{52}$ Oftentimes, all service providers, not just the founders, will receive some form of equity compensation. ${ }^{53}$ The result of all of these potential equity issuances-to founders, friends and family, angels, multiple VC funds in each of several rounds, and employees - is that a start-up might have one hundred or more direct owners by the time of a successful exit. Furthermore, because VC funds themselves have numerous owners, the start-up may ultimately have significantly more indirect owners. ${ }^{54}$

42. Id. II 105 , at $1-8$.

43. Id. . II 103, at $1-5$.

44. Id. (noting the VC fund "requires a high return on successful investments to cover its losses suffered on portfolio companies which fail ... to provide a high compound internal rate of return (' $I R R$ ') on its aggregate invested capital to compensate for the high risk of such investments")

45. Id. II 105.7, at 1-13 ("The PE/VC fund generally makes new investments into portfolio companies for a limited period of time, e.g., 5 years after formation ....").

46. Id. II 102 , at $1-3$.

47. Id. II 105.6, at 1-12

48. See Morse \& Allen, supra note 40, at 358 (noting that most start-up investing happens through staged investment and control rights in order to finance the risky investments).

49. Bankman, supra note 1 , at 1740 ("As those [design or manufacturing] milestones are reached, the company applies for additional funding from its current investors and, if necessary, new investors.").

50. See id.

51. Id.

52. LEVIN \& ROCAP, supra note 8, If 201, at 2-5 to 2-6; id. If 201.7, at 2-10 (illustrating how start-ups issue equity compensation)

53. See, e.g., Megan E. Richards, Windfall or Shortfall? Equity Compensation for Outside Service Providers, MERCER CAPITAL: FIn. REPORTING BLOG (Sept. 19, 2016), https://mercercapital.com/ financialreportingblog/windfall-or-shortfall-equity-compensation-for-outside-service-providers (discussing the trend of cash-strapped start-up companies offering equity to service providers).

54. Id. 
Start-ups tend to operate in the technology space or in other highly competitive contexts, where being first-to-market is critical. ${ }^{55}$ Thus, while a Main Street new business is akin to the proverbial slow-and-steady turtle, a startup is the boom-or-bust hare.

Finally, start-ups are expected to lose very large amounts of money, on both an annual and overall basis, before the business becomes profitable. And, the period to profitability is expected to be relatively long so that a business will often be in a loss position at the time of an exit. ${ }^{56}$ This is consistent with the high-risk, high-growth, and boom-or-bust characteristics already discussed.

55. Morse \& Allen, supra note 40, at 358 ("Daring and ambitious start-up businesses, of the sort that have fueled venture capital [] profits and built Silicon Valley's brand, are more likely to embrace new or risky projects with possibly enormous payoffs of global scope." (footnote omitted)).

56. Id. at 377 (highlighting that the majority of successful outcomes in VC-backed start-ups occur after year three). 


\section{SUMMARY}

The distinctions that are most relevant to the choice-of-entity puzzle are summarized in the following chart: ${ }^{57}$

\begin{tabular}{|c|c|c|}
\hline & Main Street Small Businesses & Start-ups \\
\hline Initial equity owners & $\begin{array}{l}\text { Founders, friends \& family } \\
(F \& F)\end{array}$ & Founders, F\&F, Angels, VC Funds \\
\hline $\begin{array}{l}\text { Follow-on equity } \\
\text { investments }\end{array}$ & $\begin{array}{l}\text { None (funded by internal } \\
\text { growth or debt) }\end{array}$ & $\begin{array}{l}\text { Numerous rounds, involving VC } \\
\text { funds }\end{array}$ \\
\hline Types of equity owners & U.S. individuals & $\begin{array}{l}\text { All types, including professional } \\
\text { and institutional investors }\end{array}$ \\
\hline $\begin{array}{l}\text { Incentive compensation } \\
\text { for non-founders }\end{array}$ & Cash bonuses & Equity (outright or options) \\
\hline Number of equity owners & Handful & Can be quite numerous \\
\hline $\begin{array}{l}\text { Investment horizon } \\
\text { before exit }\end{array}$ & Permanent & 3-7 years \\
\hline Optimal exit strategy & $\mathrm{N} / \mathrm{A}$ & IPO or strategic sale \\
\hline Growth Strategy & Slow and steady & Extremely quick and large \\
\hline Riskiness of the venture & Varies, but often not super-risky & Extremely risky \\
\hline $\begin{array}{l}\text { Importance of "first to } \\
\text { market" }\end{array}$ & Unimportant & Critical \\
\hline Early losses? & Little, if any & Extremely large \\
\hline Time to profitability & Expected to be relatively quick & $\begin{array}{l}\text { Expected to be long, often much } \\
\text { longer than investment horizon of } \\
\text { investors }\end{array}$ \\
\hline
\end{tabular}

57. See infra Subparts III.A, III.B. 


\section{TRADITIONAL EXPLANATIONS}

Several prior commentators have attempted to solve the choice-of-entity puzzle..$^{58}$ Of the three primary benefits of partnership taxation discussed above (single taxation of gains, flow-through of losses, and flexibility), these commentators focused almost exclusively on the treatment of losses. ${ }^{59}$ Start-ups typically realize large amounts of losses in the early years and will take many years to realize overall net income.$^{60}$ Furthermore, the vast majority of start-ups will never realize overall net income because so many of them ultimately fail. ${ }^{61}$ Thus, at the time of the choice-of-entity decision, the prospect of net profits seems far too speculative and remote to worry about how they might eventually be taxed if and when, despite the extremely long odds, profits could actually materialize.

In addition, even if profits are eventually realized, the profits may not be taxed more favorably if the start-up is initially classified as a partnership, rather than a corporation. Even successful start-ups are generally not significantly profitable (on an overall basis) until after an IPO or sale to a public company ${ }^{62}$ Since public companies are taxed as $\mathrm{C}$ corporations, most profits would inevitably be taxed under the double-tax $\mathrm{C}$ corporation regime regardless of how the entity was originally classified. ${ }^{63}$ In addition, because start-ups generally continue to have high rates of growth even after exit, many, if not all, of the profits in the foreseeable future would likely be plowed back into the business (instead of being immediately distributed in the form of dividends), significantly blunting the adverse impact from the second level of taxation. ${ }^{64}$ Accordingly, even if the taxation of profits was, despite being so speculative and remote, salient at the time of the choice-of-entity decision, it is not clear that initially choosing partnership classification would actually save much, if any, taxes on those profits.

58. See sources cited supra note 1.

59. See Bankman, supra note 1, at 1764-66 ("[T]he most common explanation for the industry structure [is that] [a]ttention to tax benefits from early losses runs counter to the expansive mind-set of investors and venture capitalists. 'By their very nature,' one lobbyist stated, 'the kinds of people who are going into these things are very optimistic people ...."') (quoting a lobbyist for the VC industry); Fleischer, supra note 1, at 139 (arguing that "tax losses are not as valuable as they might seem ...."); Johnson, supra note 1, at 62 ("One apologist for the Silicon Valley structures argues that "venture capital professionals who structure the deals do not share personally in the losses, so they have little reason to care about the tax effects of the losses." (quoting Victor Fleischer, The Rational Exuberance of Structuring Venture Capital Start-Ups, 57 TAX L. REV. 137, 139 (2003))).

60. See supra notes 19-20 and accompanying text

61. See Morse \& Allen, supra note 40 , at 358 ("It is understood that a start-up probably will fail.").

62. See Ben Eisen, No Profit? No Problem! Loss-Making Companies Flood the IPO Market, WaLL ST. J.: MONEYBEAT (Mar. 16, 2018, 4:20 PM), https://blogs.wsj.com/moneybeat/2018/03/16/spotify-and-dropboxto-join-a-growing-club-profitless-public-companies/ (explaining that $75 \%$ of start-ups who undergo an IPO are not profitable on even an annual basis at the time of the IPO).

63. See I.R.C. $\$ 7704$ (2012).

64. See LEVIN \& ROCAP, supra note 8, II 105.2, at 1-8 to 1-9 (describing growth-equity transactions in which start-up companies use the new capital to expand the business). 
Alternatively, the prospect of losses is certain, immediate, and highly salient. As mentioned above, start-ups lose money in the early years, often lots and lots of it. ${ }^{65}$ An extreme example is Uber, which is still losing billions of dollars every year. ${ }^{66}$ When a partnership suffers losses, those losses flow through to the owners, who can (at least in theory) use them against other income. ${ }^{67}$ When a start-up corporation suffers losses, those losses create NOLs, which can be used only if and when the corporation ultimately begins to generate annual net income ${ }^{68}$ The partnership treatment of losses seems so much better ${ }^{69}$ So why do start-ups routinely choose $\mathrm{C}$ corporation status?

\section{A. THE PRESENCE OF TAX-INDIFFERENT OWNERShIP}

One seemingly obvious answer for why start-ups choose $\mathrm{C}$ corporation status relates to the nature of the tax-indifferent owners of the start-ups. While Main Street new businesses are generally owned by U.S. individuals who would be able to use the early losses to shelter other income, start-ups are instead owned for the most part by tax-exempt organizations and foreigners who cannot. ${ }^{70} \mathrm{~A}$ majority of VC investment is made by these tax-indifferent investors, which include charities, foundations, and foreign investors. ${ }^{71}$ Accordingly, any losses realized by the $\mathrm{VC}$ funds would mostly be allocated to these investors, who, because they are not subject to U.S. income taxes, would not benefit from them..$^{72}$

This scenario is further complicated by the fact that many of these taxindifferent investors flatly refuse to invest directly in a partnership that engages in an active business. ${ }^{73}$ Tax-exempt investors generally avoid realizing unrelated business taxable income (UBTI), while foreign investors avoid income effectively connected with the United States. (ECI) ${ }^{74}$ If UBTI or ECI was allocated to these investors, they would be required to file U.S. income tax

65. See supra note 56 and accompanying text.

66. See, e.g., Shubham Kalia \& Subrat Patnaik, Uber's Third-Quarter Net Loss Widens to \$1.46 Billion: Source, REUTERS (Nov. 28, 2017, 7:04 PM), https://www.reuters.com/article/us-uber-results/ubers-third-quarternet-loss-widens-to-1-46-billion-source-idUSKBN1DTOBQ.

67. See supra note 3 and accompanying text.

68. I.R.C. $\$ 172$.

69. See Bankman, supra note 1, at 1767 ("[The VC world is] shaped by tradition, idiosyncratic investor preferences, and behavior that is hard to reconcile with any strong form of efficient market hypothesis."); see also Eric J. Allen \& Sharat Raghavan, The Impact of Non-Tax Costs on the Tax-Efficiency of Venture Capital Investments (2011 Am. Taxation Ass'n Midyear Meeting Paper: JTR Conference, July 26, 2011), http://ssrn.com/abstract=1759558 (demonstrating that VC funds are foregoing anywhere between $\$ 1.4$ to $\$ 4.4$ billion of present, after-tax cash savings).

70. LEVIN \& ROCAP, supra note 8, II 106.3, at 1-15.

71. See Gregg D. Polsky \& Brant J. Hellwig, Examining the Tax Advantage of Founders' Stock, 97 IowA L. REv. 1085, 1105 (2012) ("Approximately half of private equity fund investment is made by parties that do not pay U.S. taxes, such as pension funds, endowments, charitable foundations, and foreign persons and entities.").

72. LEVIN \& ROCAP, supra note 8 , I 1001.1, at 10-9 to $10-11$.

73. See Goldberg, supra note 1, at 943 ("Tax-exempt investors tend to prefer the corporate form ....").

74. LEVIN \& ROCAP, supra note 8, II 1001.1, at 10-9. 
returns and to pay tax on that income. ${ }^{75}$ These investors generally loathe filing U.S. tax returns, so they typically refuse to invest in $\mathrm{VC}$ funds that might require them to do so. ${ }^{76}$ While allocations of net losses do not trigger UBTI or ECI, eventual income (including gain recognized upon an exit of a flow-through investment) would. To deal with the UBTI/ECI issue, VC funds interpose a "blocker" C corporation into the structure between a partnership portfolio company and the UBTI/ECI-sensitive investors. ${ }^{77}$

Blockers do not avoid the tax paying responsibility; they merely avoid the tax reporting responsibility. ${ }^{78}$ Blockers report the UBTI/ECI income on their own corporate tax returns and pay the resulting corporate tax ${ }^{79}$ In an exit, the blocker might be the vehicle taken public, its stock might be sold, or the blocker might be merged on a tax-free basis into the buyer ${ }^{80}$ The gains from the sale of the blocker stock (or its successor in a tax-free merger) would not be UBTI/ECI income because gains from the sale of stock are characterized as investment (rather than business) income. ${ }^{81}$

The practical necessity of blockers for many VC investors may at first glance seem to answer the puzzle. After all, if a C corporation is necessary within the structure, why not just organize the start-up as a $\mathrm{C}$ corporation? In reality, however, the necessity of blockers just raises more questions.

\section{B. WHERE ARE THE TAXABLE INVESTORS?}

In the start-up context, blockers are not very tax efficient. Early losses allocated to blockers are trapped at the blocker level. Only if and when the blocker recognizes net income in any given taxable year will those losses be used to reduce taxable income and, correspondingly, corporate tax liability. ${ }^{82}$ This means that if the blocker never becomes profitable on an overall basis, some or all of those losses will evaporate into thin air. ${ }^{83}$ Even if the blocker eventually

75. Id. II 302.7, at 3-50; id. If 1001.1, at 1-9.

76. $I d$.

77. Id. If 1001.1, at 10-11.

78. BARTLETT, supra note $21, \S 3.5 \mathrm{~A}$ ("A foreign person is deemed to engage in the trade or business conducted in the U.S. by any partnership in which that foreign person is directly (or indirectly through tiers of partnerships) a partner. Every foreign person that engages in a trade or business (whether directly or indirectly through one or more partnerships) becomes a U.S. taxpayer and like other U.S. taxpayers must file U.S. federal income tax returns regardless of whether that person has any ECI or other income for a particular taxable year." (citations omitted)).

79. Crouch, supra note 25, at 210-14 to 210-15 ("Tax-exempt investors generally do not have any unrelated business taxable income ("UBTT") by owning stock in a corporation. ... A foreign investor that owns stock in a corporation generally is not subject to U.S. income tax with respect to the investment.").

80. See LEVIN \& ROCAP, supra note 8, II 105.6, at 1-12.

81. See id. $\llbracket$ 302.7, at 3-50 (explaining that a foreign investor can use a blocker to avoid direct exposure to U.S. income tax); id. I[ 512(b)(5) (excluding gains from UBTI).

82. Corporations only need to pay tax on income and not on losses.

83. Johnson, supra note 1, at 31 (discussing how start-up losses relating to research and development are "trapped"). 
does become profitable on an overall basis, the time-value of money eats into the value of the losses because of their delayed utilization. ${ }^{84}$

Recall that start-ups, even the relatively rare successful ones, lose lots of money in the early years. ${ }^{85}$ In light of these losses and the tax inefficiency of blockers, Professor Joseph Bankman argued in 1994 that the ideal investors in $\mathrm{VC}$ funds would be taxable investors with large amounts of taxable income, particularly profitable $\mathrm{C}$ corporations. ${ }^{86}$ Bankman focused on U.S. corporate investors, and not U.S. individual investors, because C corporations are not subject to the passive activity rules that apply to individuals. ${ }^{87}$ These passive activity rules and their impact on the willingness of U.S. individuals to invest in VC funds are discussed below. 88

Bankman argued that corporate investors with lots of profits would be ideal VC investors because they could use the large early losses to immediately shelter some of their ordinary course income. ${ }^{89}$ This would mean that (1) the losses would surely be utilized (because the corporations would have lots of ordinary course income to offset) and (2) such utilization would be immediate..$^{90} \mathrm{But}$ in practice, corporate investors rarely participate to a significant extent in $\mathrm{VC}$ funds and their overall percentage of $\mathrm{VC}$ investment dollars is extremely low. ${ }^{91}$ Bankman tried to explain this piece of the puzzle, admittedly without reaching a satisfying conclusion. ${ }^{92}$ His best guess was that the absence of corporate investment was perhaps due to a combination of a corporate myopic focus on financial accounting consequences (as opposed to real after-tax cash-flow results) and path dependence by corporate and VC fund managers. ${ }^{93}$

This hard-to-explain phenomenon that Bankman observed nearly twentyfive years ago apparently has not changed and, in fact, may have become even more perplexing. ${ }^{94}$ Since Bankman's article, there has been tremendous growth

84. See Michael G. Cooper \& Matthew J. Knittel, The Implications of Tax Asymmetry for U.S. Corporations, 63 NAT'L TAX J. 33, 35 (2010) (explaining the erosion of the value of net operating losses caused by delays in claiming carryforward deductions).

85. See supra Subpart II.B.

86. Bankman, supra note 1 , at $1754-55$

87. Id. at 1753-54 ('In general, these [passive loss] rules limit the ability of individuals who invest in businesses that they do not actively manage, 'passive activities,' from using flow-through losses from such businesses to offset salary income, or investor-level income from portfolio investments such as stocks and bonds."). See generally I.R.C. $\$ 469$ (2012).

88. See infra Subpart III.D.3.

89. Bankman, supra note 1 , at 1754.

90. Id.

91. Id. at 1755 ("To put the matter somewhat differently, the presence of institutional and tax-constrained investors may be the result, rather than the cause, of the present organizational structure.").

92. Id. at 1766 ("There is no single answer to the riddle of start-up organization.").

93. Id. at 1767 ("The price of stock is hypothesized to reflect after-tax return, and to therefore rise with tax savings. In practice, many corporate decision-makers do not believe the market 'looks-through' financial reporting. As a result, corporations appear to sacrifice tax benefits at the altar of reported earnings.").

94. Cf. Understanding Venture Capital, FunDERSCLuB, https://fundersclub.com/learn/guides/vc101/understanding-venture-capital/ (last visited Jan. 19, 2019) (noting that VC investment funding stems from family offices, institutional investors (such as pensions, endowments, and sovereign wealth funds, and high networth individuals). 
in the VC industry. ${ }^{95}$ Yet, corporations by and large continue to decline to invest significantly in VC funds. ${ }^{96}$ The remainder of this Article assumes that this will continue.

\section{WHERE TO INSERT THE BLOCKER?}

The existence of tax-exempt and foreign investors necessitates the insertion of a blocker between those investors and the start-up. ${ }^{97}$ When (as is common) a start-up is formed as a corporation, the start-up effectively is the blocker. Alternatively, each start-up can be formed as an LLC with a separate blocker immediately above each LLC to block only the investors who need it, with the remaining investors unblocked. Another option would be to have a "mothership" blocker hold interests in all (or multiple) start-ups formed as LLCs. Finally, given the ubiquity of tax-exempt and foreign investors in the U.S. public company shareholder base, when U.S. public corporations invest in start-ups, the investor is effectively the blocker.

\section{The Investor as Blocker}

Tax-exempts and foreigners own a significant portion of the equity in U.S. public companies. ${ }^{98}$ When these public companies invest in $\mathrm{VC}$ funds and when those VC funds invest in LLC start-ups, then the public company is effectively serving as the blocker. ${ }^{99}$ This model was essentially what Bankman was envisioning when he described the phenomenon of the missing corporate investors. ${ }^{100}$ The benefit of "investor as blocker" is that early losses generated by start-up investments could be used against all of the investor's income and gains, whether they are from ordinary business operations (for example, selling widgets) or investments (for example, selling interests in successful start-ups).

In practice, there is relatively little corporate investment in start-ups, whether through VC funds or directly. ${ }^{101}$ Instead, the blocker is almost always inserted further down the ownership chain. ${ }^{102}$ The rationales for this are far from obvious and were previously explored by Bankman. ${ }^{103}$

\section{Mothership Blocker}

Once the possibility of large corporate investment in start-ups is taken off the table, a mothership blocker structure might be considered. The mothership

\footnotetext{
95. See Kyle Stanford, The State of the US Venture Industry in 15 Charts, PITchBook (Jan. 26, 2018) https://pitchbook.com/news/articles/the-state-of-the-us-venture-industry-in-15-charts.

96. See infra note 94

97. See supra Subpart III.A.

98. See Steven M. Rosenthal \& Lydia S. Austin, The Dwindling Taxable Share of U.S. Corporate Stock, 151 TAX NOTES 923, 928-29 (2016).

99. See Bankman, supra note 1 , at 1763.

100. Id.

101. See id. at 1759 .

102. Id.

103. Id.
} 
blocker would own interests in many, if not all, of the start-up LLCs in which a fund is invested. ${ }^{104}$ One benefit of this is that, if some of the start-ups were profitable, while others were incurring losses, the profits could be absorbed by the losses at the mothership blocker level. In the alternative "separate blockers" structure, where each investment has its own blocker, no such netting is possible, so profitable blockers pay full tax, while unprofitable blockers incur unusable losses.

In practice, mothership blockers are not used.$^{105}$ One potential explanation is that start-up investments are all expected to generate losses (or at least none of the start-ups are expected to have significant income) during the period they are held by the VC fund. ${ }^{106}$ This means there would be little or no ordinary business profits realized by the mothership blocker. But even though it is true that there may be no ordinary business profits, there will likely be a very large amount of profits realized upon the exits of the successful businesses. As explained in detail below, one of the more subtle advantages of LLC classification is that, upon such an exit, the transaction can be structured as an asset sale. ${ }^{107}$ An asset sale gives the buyer a stepped-up basis ("SUB") in the LLC's assets, which should increase the price the buyer is willing to pay by about $20 \% .{ }^{108}$ Delivering a SUB is normally prohibitively expensive for a corporation, but not so for an LLC, as more fully described below. ${ }^{109}$ In the case of a mothership blocker, when the few successful LLC start-ups are exited, the blocker's losses from all of its other investments could be used to absorb the gains from the asset sales by LLCs.

Nevertheless, as previously mentioned, mothership blockers are not common. Instead, a blocker is typically formed for each LLC investment or, more commonly, the start-up itself is formed as a $\mathrm{C}$ corporation, which means the start-up itself is effectively the blocker.

\section{Separate Blockers for Each Start-Up}

In the relatively rare cases where start-ups are organized as LLCs, a separate blocker is usually formed for each start-up LLC investment. ${ }^{110}$ The investors who need blockers invest through the blocker, while the other investors make direct investments in the LLC. ${ }^{111}$ Upon exit, the blocked investors would often sell the blocker stock, because a sale of the blocker's assets would create prohibitive tax consequences due to the double taxation of the gains, even

\footnotetext{
104. LEVIN \& ROCAP, supra note 8, II 1001.1, at 10-11.

105. Id. (separate blocker generally formed for each LLC investment).

106. See supra Subpart II.B.

107. See infra Subpart IV.C.1.

108. See infra Subpart IV.C.1.

109. See infra Subpart IV.C.1.

110. LEVIN \& ROCAP, supra note 8, II 1001.1, at 10-11.

111. John LeClaire \& Jamie Hutchinson, Examining the 'Blocker', PRIVCAP (2016), https://www privcap.com/wp-content/uploads/2016/05/Examining-the-Blocker.pdf.
} 
though the buyer should (in theory) pay a hefty premium for the assets. ${ }^{112}$ Alternatively, the blocker could be merged, on a tax-free basis, into the acquirer, or the blocker vehicle could be taken public.

The separate blocker structure might appear to be less efficient than the mothership structure for two interrelated reasons. First, all of the losses with respect to failed start-ups would evaporate into thin air. Those losses would be trapped in the separate blocker corporations, each of which has no income or gains against which to use them. In the mothership structure, those losses could absorb gains upon the exit of the relatively few successful structures. Second, this cross-utilization of losses could allow exits of the successful ventures to be structured as asset sales, rather than stock sales (or tax-free mergers). This would give the buyer a SUB, which can result in an approximately $20 \%$ purchase price premium. ${ }^{113}$

To compare the mothership and separate blocker structures, consider a VC fund that makes twenty start-up investments of $\$ 1,000,000$ each:

\begin{tabular}{|l|l|l|l|}
\hline $\begin{array}{l}\text { Investment \# } \\
\text { (sales price) }\end{array}$ & Investment Total & Sales Proceeds Total & Gain or (Loss) \\
\hline $\mathbf{1 - 1 4}$ (busts) & $\$ 14,000,000$ & $\$ 0$ & $(\$ 14,000,000)$ \\
\hline $\mathbf{1 5 - 1 6}(\mathbf{1 x})$ & $\$ 2,000,000$ & $\$ 2,000,000$ & $\$ 0$ \\
\hline $\mathbf{1 7}(\mathbf{2 x})$ & $\$ 1,000,000$ & $\$ 2,000,000$ & $\$ 1,000,000$ \\
\hline $\mathbf{1 8}(\mathbf{5 x})$ & $\$ 1,000,000$ & $\$ 5,000,000$ & $\$ 4,000,000$ \\
\hline $\mathbf{1 9}(\mathbf{1 0 x})$ & $\$ 1,000,000$ & $\$ 10,000,000$ & $\$ 9,000,000$ \\
\hline $\mathbf{2 0}(\mathbf{2 0 x})$ & $\$ 1,000,000$ & $\$ 20,000,000$ & $\$ 19,000,000$ \\
\hline Total & $\$ 20,000,000$ & $\$ 39,000,000$ & $\$ 19,000,000$ \\
\hline
\end{tabular}

If each of these investments was held by a separate blocker, the exits would be structured as sales of the blocker interests, leaving the buyer with a carryover basis instead of a SUB. The investors would walk away with $\$ 39,000,000$ because the $\$ 19,000,000$ capital gain on the sale of the blocker stock would not be subject to tax. (It is assumed for the sake of simplicity that all of the investors in the fund are tax-exempt or foreign and therefore all of the investments are fully blocked and no taxes are imposed on capital gains.)

If a mothership blocker was used instead, the blocker could sell assets and therefore would deliver SUBs to the buyer. Assuming a 20\% premium for the 
SUB, the aggregate sales proceeds would increase from $\$ 39,000,000$ to approximately $\$ 47,000,000$. Assuming the blocker was capitalized with a $1: 1$ debt/equity ratio and the debt bore a $9 \%$ interest rate with an average maturity of six years, ${ }^{114}$ the blocker would generate an aggregate interest deduction of about $\$ 7,000,000$. (The interest income received by the investors with respect to the debt is neither UBTI nor ECI.) The overall corporate taxable income would be $\$ 20,000,000$ ( $\$ 47,000,000$ in total sales proceeds minus $\$ 20,000,000$ for research, development, and other miscellaneous costs deductions, and then less $\$ 7,000,000$ for interest), and the tax would equal $\$ 7,000,000$, leaving the investors with approximately $\$ 40,000,000$. This is $\$ 1$ million more than when separate blockers were used. Thus, under these facts, the mothership blocker is slightly more efficient.

Obviously, a change in the assumptions could drastically affect the analysis. Most notably, the success of the fund is a critical input. Leaving all the other assumptions constant, a fund with a $2.15 \mathrm{x}$ overall return (instead of a $1.95 \mathrm{x}$ return) would be in roughly the same position whether or not it used a mothership blocker or separate blockers. ${ }^{115}$ Funds that do better than $2.15 \mathrm{x}$ would be better off using separate blockers. For example, for a fund with a $3 x$ return, separate blockers save roughly $\$ 4$ million compared to using a mothership. And a 5x fund would save $\$ 13$ million, and a 10x fund $\$ 35$ million. For these very successful funds, the benefit of avoiding corporate tax on the mothership's net gain would be large enough to overcome the separate blocker structure's lack of SUB premiums on the winning investments and its inability to cross-utilize the losses from the losing investments.

In short, the mothership blocker structure would marginally help VC funds with middling performance. But good funds would generally be better off using separate blockers, and outstanding funds would be much better off. ${ }^{116}$

\section{The Start-Up as Blocker}

As a final option, each start-up could itself serve as the blocker. In that case, each start-up is organized as a separate corporation. This is the traditional approach, and it still remains the standard start-up structure in Silicon Valley.

The difference between having the start-up itself as the blocker and having a separate blocker for each LLC start-up is relevant only to investors who do not require blockers ("unblocked investors"). Unblocked investors include U.S. individuals, U.S. corporations, and certain tax-exempt organizations that are exempt from the unrelated business income tax ("super tax-exempts") and are

114. The example assumes that each LLC portfolio company was purchased by the blocker using $50 \%$ debt proceeds and $50 \%$ equity proceeds and the average maturity period of each borrowing to purchase a portfolio company was six years.

115. Let $x$ be the equivalent $\mathrm{COB}$ purchase price. $x=1.2 x-[(1.2 x-27) .35]$. Using the assumptions above, $x=43$. An investment of 20 yielding 43 is a $2.15 \mathrm{x}$ return.

116. Another problem is the dividend withholding tax with respect to foreign investors upon periodic distributions from the mothership. In the separate blocker structure, blocker stock is sold upon each successful exit, resulting in capital gain rather than dividend income, so the withholding tax does not apply. 
therefore not concerned with realizing UBTI. ${ }^{117}$ The potential benefits these unblocked investors would receive, by investing in an LLC start-up as opposed to a corporate start-up, are threefold. First, any income realized is taxed once and only once. ${ }^{118}$ Second, any losses that are realized flow through the LLC, instead of being trapped in a corporate entity. ${ }^{119}$ Third, upon a successful exit, the unblocked investors can efficiently deliver a SUB to the buyer, which should increase the price that the buyer is willing to pay to those investors by approximately $20 \% .{ }^{120}$ This third benefit can be thought of as merely a specific application of the first benefit. If the start-up was a corporation, the gain on the sale of assets to the buyer would be prohibitively expensive. This is because the immediate double tax burden borne would exceed the purchase price premium. The unique ability of LLCs to efficiently deliver SUBs to buyers is discussed in much greater detail below. ${ }^{121}$

In most start-up situations, the second and third benefits are the only potentially relevant ones. The first is largely irrelevant because start-ups are not typically expected to generate ordinary business profits (on an overall basis) before they are exited. Because exits normally involve the start-up becoming, or being acquired by, a public company, those business profits, if and when they are realized, will inevitably be subject to the double tax regime. On the other hand, start-ups are expected to realize lots of losses before they are exited. In addition, successful exits are expected to result in large gains, with "home runs" resulting in monumental gains.

\section{TREATMENT OF THE UNBLOCKED INVESTORS}

When a start-up is formed as an LLC, only unblocked investors get the two benefits described above (loss flow through and the ability to deliver a SUB to a buyer). When the start-up is formed as a corporation, those benefits are denied to all investors. This Subpart explains the unblocked investors' benefits in detail.

\section{Super Tax-Exempts}

State and local governments, as well as Indian tribes, are immune from UBIT under $\$ 115$ of the Internal Revenue Code (IRC). ${ }^{122}$ In addition, pension funds for state and local employees often interpret $\$ 115$ to provide the same immunity for themselves. ${ }^{123}$

117. Eric M. Elfman et al., Corporate Tax Issues in Private Equity, A.B.A., at 26 (Jan. 23, 2014), https://beta.americanbar.org/content/dam/aba/events/taxation/taxiq/mid14/taxiq-14mid-ct-taxissues-huckslides.pdf

118. Id. at 11.

119. See discussion of loss flow-through supra Subpart I.B.

120. See discussion of SUB premium infra Subpart IV.C.1.

121. See infra Subpart IV.C.

122. I.R.C. $\$ 115$ (2012).

123. See Calvin H. Johnson \& Ellen P. Aprill, UBIT to the Defense! ESOPs and Government Entities, 128 TAX NOTES 317, 318 (2010) ("Pension funds for state and local employees have also claimed immunity from UBIT, relying at least in part on section 115 , although it is not clear that they were all entitled to immunity on 
Accordingly, these types of investors can invest directly in a start-up LLC without worrying about UBIT consequences. Because these investors do not pay income tax, the loss flow-through benefit is nil. Instead, the major benefit is that, upon exit, these investors can sell their share of the start-up's assets, whereas blocked investors must, as a practical matter, sell blocker stock. ${ }^{124}$ This allows the super tax-exempts to deliver a SUB and receive a corresponding premium in the sales price. Because super tax-exempts do not pay taxes, the after-tax benefit from receiving the SUB premium would equal the pre-tax premium. ${ }^{125}$

\section{Domestic Corporate Investors}

Domestic corporations can easily invest directly in LLC start-ups. And, as explained above, corporate investors that have significant profits are theoretically the ideal VC investors because they can immediately utilize the large losses thrown off by LLC start-ups. ${ }^{126}$ And, when the start-up investment is exited, they can receive the roughly $20 \%$ SUB premium on the purchase price of their interest. ${ }^{127}$ Because the corporate investor would pay tax on all of the gain (including the premium), the after-tax benefit of the premium would be approximately $13 \%$ (under the historical $35 \%$ corporate tax rates). ${ }^{128}$ As previously discussed, significant domestic corporate investment in start-ups is relatively rare. ${ }^{129}$

However, it should be noted that one of the underappreciated problems with using partnerships relates to tax compliance, which is discussed extensively in Subpart IV.A. Compliance concerns would create particular problems for large public companies who must regularly prepare and file up-to-date financial statements. These practical compliance concerns could help explain some of the unattractiveness of corporate investment in start-ups, notwithstanding its tax efficiency.

that basis."); Andrew W. Needham \& Anita Beth Adams, Private Equity Funds, TAx MGMt. (BNA) 735-3d, VIII.A.2.b. ("Most pension funds organized for the benefit of state and local government employees (including employees of governmental affiliates) claim complete immunity from tax, relying at least in part on $\S 115$. It is not entirely clear, however, that such income is derived from the exercise of an essential governmental function, accrues to a state or political subdivision (rather than the employees) or does not benefit private interests."); see also I.R.S. Priv. Ltr. Rul. 2015-37-019 (Sept. 11, 2015) (holding that I.R.C § 115 covers multiple employer trusts established to enable public-agency employers to fund post-retirement employee benefits); I.R.S. Priv. Ltr. Rul. 2015-16-031 (Apr. 17, 2015); I.R.S. Priv. Ltr. Rul. 2015-15-016 (Apr. 10, 2015).

124. See discussion of SUB premium infra Subpart IV.C.

125. If the portfolio company was structured as a corporation, a buyer might pay a premium for the company's net operating loss carryforwards. However, the SUB premium received for selling an LLC should exceed the value of the existing NOL carryforwards.

126. See supra Subpart III.B.

127. See discussion of SUB premium infra Subpart IV.C.

128. $20 \%$ SUB premium $x(1-.35)=13 \%$.

129. See supra Subpart III.B. 


\section{Individual U.S. Investors}

Individual investors often invest in $\mathrm{VC}$ funds, though the extent of their investment can vary dramatically from fund to fund. ${ }^{130}$ Individuals may invest in a variety of ways. Individual $\mathrm{VC}$ fund managers are often required to personally invest a small percentage (usually 1 to $10 \%$ ) of the capital to give the investors comfort that they have some "skin in the game." 131 Individual VC fund managers also receive carried interest, which entitles them to a percentage of the fund's profits (usually 20\%). ${ }^{132}$ Occasionally, wealthy individuals or families invest either directly in $\mathrm{VC}$ funds or in a pooled investment vehicle made up of individual owners. ${ }^{33}$ For example, a fund of funds receives capital from high net worth individuals and makes investments in VC or other private funds. ${ }^{134}$ The fund of funds allows for greater diversification, which may be difficult for some investors to achieve due to high minimum capital commitments of the investee funds. ${ }^{135}$

Regarding the loss flow-through benefit, only capital investors (and not carried interest holders) are allocated net losses, because carried interest holders only participate in net gains. ${ }^{136}$ Individual capital investors bear net losses and, accordingly, will be allocated a share of them. These net losses will be characterized as passive activity losses ("PALs") unless the investor materially participates in the LLC's activities, which would be rare. ${ }^{137}$ Until a particular activity is exited completely by the investor (for example, in a complete disposition of an LLC interest), PALs from the activity may only be used to absorb passive activity gains. ${ }^{138}$ As the vast majority of start-ups will generate losses until they are either exited or abandoned, in practice this rule delays the utilization of PALs until those events because there are no passive activity gains except upon exit. This delayed utilization of PALs reduces the value of the flowthrough losses due to the time-value of money. ${ }^{139}$

Another burden from PAL characterization is that, in the hands of some individual investors in start-ups, the losses may end up being utilized to soak up

130. Understanding Venture Capital, FUNDERSCLUB, https://fundersclub.com/learn/guides/vc101/understanding-venture-capital/ (last visited Jan. 19, 2019).

131. Preqin, Preqin Special Report: Private Capital Fund Terms 11 (2016), http://docs.preqin.com/reports/Preqin-Special-Report-Private-Capital-Fund-Terms-November-2016.pdf

(showing median general partner commitments of approximately $2 \%$ and mean general partner commitments of approximately $5 \%$ for all private equity funds).

132. LEVIN \& ROCAP, supra note 8, IT 102, at 1-3.

133. $C f$. Subpart III.A (explaining that the majority of private equity investment is made by institutional or foreign investors).

134. Venture Capital, BUS. BROKERAGE GROUP, https://www.businessbrokeragegroup.com/venturecapital/venture-capital (last visited Jan. 19, 2019).

135. Id.

136. LEVIN \& ROCAP, supra note 8, II 102, at 1-3.

137. I.R.C. $\$ 469$ (2012).

138. Id.

139. See generally Daniel S. Goldberg, The Passive Activity Loss Rules: Planning Considerations, Techniques, and a Foray into Never-Never Land, 15 J. REAL EST. TAX'N 3 (1987). 
capital gains, which are taxed at approximately half the rate of ordinary income. ${ }^{140}$ For example, assume an investor realizes $\$ 1,000,000$ of PALs in each of Years 1 through 5 and then in Year 6 realizes a $\$ 10,000,000$ long-term capital gain, which constitutes a passive activity gain. If the investor has a relatively small amount of ordinary income (such as compensation) in Year 6, the $\$ 5,000,000$ PALs from Years 1 through 5 would mostly absorb the capital gain recognized in Year 6. The overall effect of the PAL limitation in such a case is the conversion of the PALs from ordinary losses to a capital loss (as well as the more obvious deferral of losses from Years 1 through 5 until Year 6).

The PAL rules therefore delay suspended losses and potentially effectively convert their character to capital losses. This is similar to what would have happened if the start-up was initially formed as a corporation. In that case, instead of realizing annual PALs, the investor includes his investment in his stock basis. If the start-up fails, the stock will be worthless and the investors will, at the time of worthlessness, realize a long-term capital loss equal to their stock basis. If the start-up succeeds, the stock will be sold and, at the time of the sale, the investors will, at the time of the sale, use the stock basis to offset their longterm capital gain recognized on the sale.

Accordingly, the PAL rules effectively can erode much, if not all, of the benefit of flow-through losses for individuals. However, there may still be some benefit in some situations. If the investor has significant ordinary income, the PALs would offset that high-rate income when they are released. In addition, PALs are released when any passive activity gains are generated (to the extent of those gains), regardless of whether the gains stem from the same investments that generated the PALs. ${ }^{141}$ On the other hand, basis in stock is recovered only when that particular stock is sold or becomes worthless. ${ }^{142}$ To illustrate these points, assume that an investor invests $\$ 1$ million in five different investments, resulting in $\$ 1$ million of PALs in each of Years 1 through 5. In Year 6, one of the investments is sold for $\$ 10$ million. In Year 7, the other four investments become worthless.

\footnotetext{
140. See I.R.C. $\$ 1$ (providing a maximum $37 \%$ rate on ordinary income and a $20 \%$ rate on long-term capital gains).

141. See id. $\$ 469$ (a)-(b).

142. See id. $\$ 1001$ (a) (requiring a realization event, such as a sale or exchange, before a loss is realized); see also id. $\S 165(\mathrm{~g})$ (treating the worthlessness of a security as a deemed sale).
} 


\begin{tabular}{|l|l|l|l|l|l|l|}
\hline Investment & $\# 1$ & $\# 2$ & $\# 3$ & $\# 4$ & $\# 5$ & Total \\
\hline $\begin{array}{l}\text { Amount } \\
\text { invested }\end{array}$ & $\$ 1$ million & $\$ 1$ million & $\$ 1$ million & $\$ 1$ million & $\$ 1$ million & \$5 million \\
\hline $\begin{array}{l}\text { Losses in } \\
\text { Years 1 } \\
\text { PALs) }\end{array}$ & $(\$ 1$ million) & $(\$ 1$ million) & $(\$ 1$ million $)$ & $(\$ 1$ million) & $(\$ 1$ million $)$ & (\$5 million) \\
\hline Year 6 Exit & $\begin{array}{l}\text { Sold for } \\
\$ 10 \mathrm{M}\end{array}$ & N/A & N/A & N/A & N/A & N/A \\
\hline Year 7 & N/A & Worthless & Worthless & Worthless & Worthless & N/A \\
\hline
\end{tabular}

Under the PAL rules, the $\$ 5$ million of PALs from all the investments are released in Year 6, and they reduce the investor's capital gain on the exit from $\$ 10$ million to $\$ 5$ million. ${ }^{143}$ Assuming a $20 \%$ capital gains rate, the investor would be left with $\$ 9$ million in cash $(\$ 10$ million cash proceeds less $\$ 1$ million capital gains tax) in Year 6. In Year 7, when the four other investments become worthless, there are no tax consequences. ${ }^{144}$

If all the investments were instead structured as corporations, the sales price of investment \#1 needs to be adjusted. Because the start-up is a corporation, the sale would have to be structured as a sale of stock, which means the buyer will not pay the SUB premium. ${ }^{145}$ Thus, the purchase price should be (assuming a $20 \%$ SUB premium) $\$ 8.33$ million rather than $\$ 10$ million. ${ }^{146}$ However, to isolate the impact of the PAL rules, assume that the purchase price of investment \#1 remains $\$ 10$ million. In that case, the gain recognized will be $\$ 9$ million and the tax due $\$ 1.8$ million, resulting in $\$ 8.2$ million in after-tax cash. The worthlessness of the other investments in Year 7 will result in $\$ 4$ million of capital losses realized in that year. The results are summarized below:

\footnotetext{
143. This assumes that the investor has no ordinary income in Year 6.

144. This is because the losses from Investments 2 through 5 were used in Year 6 .

145. See discussion of SUB premium infra Subpart IV.C.1.

146. $\$ 8.33$ million $\times 1.2=\$ 10$ million.
} 


\begin{tabular}{|l|l|l|l|}
\hline Year(s) & Flow-Through & Corporate & Difference \\
\hline $\mathbf{1 - 5}$ & No tax consequences & No tax consequences & None \\
\hline $\mathbf{6}$ & $\begin{array}{l}\text { \$5M capital gain; } \$ 9 \\
\text { million after-tax cash }\end{array}$ & $\begin{array}{l}\text { \$9 capital gain; } \$ 8.2 \mathrm{M} \\
\text { after-tax cash }\end{array}$ & $\begin{array}{l}\text { Corporate investment } \\
\text { reduces after-tax cash by } \\
\$ 800 \mathrm{~K}\end{array}$ \\
\hline $\mathbf{7}$ & No tax consequences & $\begin{array}{l}\text { \$4M long-term capital } \\
\text { losses }\end{array}$ & $\begin{array}{l}\text { Corporate investment } \\
\text { provides } \$ 4 \mathrm{M} \text { more long- } \\
\text { term capital losses }\end{array}$ \\
\hline
\end{tabular}

In general, the flow-through consequences are marginally better. If the capital losses from worthlessness in Year 7 can be used immediately to offset capital gains otherwise taxed at $20 \%$, there is only a one-year acceleration of the utilization of the $\$ 4$ million of losses from Investments 2 through 5. If the utilization of the Year 7 capital losses is delayed beyond year 7, the time-value benefit grows.

In summary, in the context of taxable individual investors, the PAL limitations restrict the ability to use flow-through losses in such a way that the benefit of flow-through losses, relative to trapped losses, is often insignificant. Thus, the benefit of loss flow-through to individual investors is generally not an important factor in entity classification.

More important than flow-through losses is the LLC's unique ability to deliver a SUB in successful exits, which is discussed below. ${ }^{147}$ The SUB delivery should theoretically result in a premium equal to roughly $20 \%$ of the value of successful exits. ${ }^{148}$ Since the premium would result in additional capital gain, the after-tax premium for individual investors would equal roughly $16 \%$ of the equivalent $\mathrm{COB}$ purchase price. ${ }^{149}$ No such premium is available if the start-up is structured as a corporation.

147. See infra Subpart IV.C.1.

148. See discussion of SUB premium infra Subpart IV.C.1.

149. $20 \%$ assumed SUB premium $x(1-20 \%$ long-term capital gains $)=16 \%$. 


\section{Summary of Tax Benefits from LLC Versus Corporate Start-Up Investments}

The following chart summarizes the above conclusions:

\begin{tabular}{|l|l|l|l|}
\hline Type of Investor & $\begin{array}{l}\text { Benefit from Loss } \\
\text { Flow-Through (relative } \\
\text { to corporate } \\
\text { classification) }\end{array}$ & $\begin{array}{l}\text { Theoretical Benefit } \\
\text { from Delivering SUB } \\
\text { (expressed as a } \\
\text { premium to equivalent } \\
\text { COB purchase price \& } \\
\text { in after-tax terms) }\end{array}$ & Comments \\
\hline $\begin{array}{l}\text { Blocked Investors } \\
\text { (foreign \& most tax- } \\
\text { exempts) }\end{array}$ & None (blocked) & $\begin{array}{l}\text { None (must deliver } \\
\text { blocker stock) }\end{array}$ & No tax on premium \\
\hline Super Tax-Exempts & $\begin{array}{l}\text { None (no tax } \\
\text { responsibilities) }\end{array}$ & 20 percent premium & $\begin{array}{l}35 \text { percent corporate } \\
\text { tax applied on } \\
\text { premium }\end{array}$ \\
\hline U.S. Corporations & $\begin{array}{l}\text { Inmediate utilization of } \\
\text { losses to shelter 35\% rate } \\
\text { income }\end{array}$ & 13 percent & $\begin{array}{l}20 \text { percent tax on } \\
\text { capital gains applied } \\
\text { to premium }\end{array}$ \\
\hline U.S. Individuals & $\begin{array}{l}\text { PAL rules significantly } \\
\text { reduce their benefit }\end{array}$ & 16 percent & \\
\hline
\end{tabular}

Accepting as true the reluctance of U.S. corporations to significantly participate in VC investments, the only significant benefit of LLC classification is the ability to generate a SUB premium.

\section{E. OTHER IDENTIFIED FACTORS SUPPORTING THE CORPORATE CHOICE}

The existing literature has identified other factors that push in favor of the corporate form for start-ups. Some have noted that LLCs were historically far less familiar than corporations. ${ }^{150}$ This differential has eroded to some extent now that LLCs have been around for over forty years. ${ }^{151}$ The familiarity gap is perhaps most salient with respect to incentive compensation. While corporations issue ubiquitous stock options, LLCs typically issue far more obscure profits interests. ${ }^{152}$ Profits interests are economically very similar to stock options, and

150. See Bankman, supra note 1 , at 1751 (quoting one venture capitalist as saying: "Management gets spooked by partnership interests.").

151. See Fleischer, supra note 1, at 173 (noting that "the first LLC statute was passed in 1977 [in Wyoming]").

152. See Polsky \& Hellwig, supra note 71 , at 1105 (discussing profits interests in the private equity and VC fund context). 
in fact, can yield better tax consequences for holders. ${ }^{153}$ However, VC experts understand that start-up employees place a higher value on stock options than on functionally equivalent profits interests because options are so much more prevalent and familiar. ${ }^{154}$

In addition, IPO exits are marginally "smoother" for corporations. ${ }^{155}$ As public firms are generally subject to the corporate tax regardless of their tax classification and the public market prefers the corporate form, LLCs that go public generally first need to convert to a corporation. ${ }^{156}$ However, starting as an LLC puts only a grain or two of sand in the gears during the going-public process. Tax-free conversion from an LLC to a corporation will in most cases involve a relatively simple set of corporate transactions. ${ }^{157}$ In 1994, Bankman estimated these transaction costs to be no more than $\$ 200,000,{ }^{158}$ which in today's dollars would approximate $\$ 350,000 .{ }^{159}$ Even if the costs were as high as $\$ 500,000$, this amount would commonly pale in comparison to the benefit of being able to deliver a SUB. For instance, assuming $40 \%$ of a start-up is owned by unblocked investors (including founders, super-tax exempts, and VC fund managers), a $20 \%$ SUB premium, and a $\$ 1$ billion pre-IPO valuation, the SUB premium would equal $\$ 80,000,000$.

Exits other than IPOs can likewise be marginally easier for corporations. In a strategic sale to a public company buyer with all or nearly all of the consideration paid in the form of buyer stock, the transaction can easily be structured as a tax-free merger if the start-up is a corporation. ${ }^{160}$ If the start-up is an LLC, the same transaction would now be typically structured as a so-called "Up-C," which is a relatively new transaction structure that provides even better tax consequences than a tax-free merger, but with some significant additional complexity and transaction costs. ${ }^{161}$

153. See Goldberg, supra note 1, at 938 ("One could fashion a similar plan creating options (nonqualified only) to purchase partnership/LLC interests."); $c$. $i d$. at 939 (noting that the "granting of a capital interest in a partnership ... does not deal with the consequences to a partnership that was already in existence" and discussing the complexity of "revaluation of its assets and provid[ing] special allocations of gain ... to reflect in each old and new partner's capital account"); Bankman, supra note 1, at 1752-53 (discussing that if employees received partnership interests, they would be treated as being a "partner for tax purposes" which would "complicate[] tax filings and impose[] some additional legal and accounting fees on the venture and the employee"). "Unit options," options on LLC units that are functionally equivalent to stock, while theoretically possible, are disfavored by tax experts because it is not clear how they are taxed, and there is the possibility of quite unfavorable (and counterintuitive) tax results upon exercise of those options.

154. See Goldberg, supra note 1, at 943 ("Perhaps [granting partnership interests], while theoretically sound, ignores an important perception - stock options may be a means of attracting young high-tech but financially unsophisticated employees, ready to overvalue the options as compensation and therefore accept less cash compensation than the actual value of the options would warrant.").

155. Fleischer, supra note 1, at 175.

156. See id. at $177-82$.

157. See generally LEVIN \& ROCAP, supra note 8 .

158. Bankman, supra note 1 , at 1750 .

159. See U.S. Inflation Rate, $\$ 200,000$ in 1994 to 2018 , CPI INFLATION CALCULATOR, http://www.in2013dollars.com/1994-dollars-in-2018?amount=200000 (last visited Jan. 19, 2019).

160. See Fleischer, supra note 1, at 182-83.

161. See generally Polsky \& Rosenzweig, supra note 2 . 


\section{UNDERAPPRECIATED FACTORS ENCOURAGING CORPORATE Classification}

The previous Part described the traditional explanations for why start-ups prefer the corporate form. These explanations focused on the presence of taxindifferent investors, the absence of corporate investors, loss limitations imposed on individual investors, and unfamiliarity and additional transaction costs associated with the use of LLCs. ${ }^{162}$

However, two significant factors, both of which push in favor of corporate classification, have thus far been tremendously underappreciated. First, the unique nature of flow-through taxation creates numerous compliance and transaction complications that are not present in the corporate context. ${ }^{163}$ While previous commentators have mentioned complexity as a factor, they did not appreciate its significance or explore the true sources of the complications. ${ }^{164}$ Second, while in theory the most significant benefit of using the LLC form is the ability to deliver a SUB to the buyer, which should pay a premium for it, there is significant skepticism about whether buyers in typical exits of start-ups are actually willing to pay such a premium. ${ }^{165}$ Thus, the administrative problems of using an LLC have been understated, while a significant benefit - the ability to fetch a SUB premium-is missing in the start-up context.

\section{A. COMPLIANCE AND COMPLEXITY}

The existing literature, while recognizing that corporations are more simple than LLCs, has misunderstood the real sources and key impacts of LLC-related complexity. Numerous and cascading K-1s, exceptionally high failure rates, disorderly liquidations, and transactional complexity combined with the fastpaced, cookie-cutter, and cash-poor early stage VC environment make widespread use of LLCs extremely impractical.

\section{Existing Literature}

Prior commentators have noted some additional compliance and complexity costs associated with LLCs. Professor Joseph Bankman, in the first academic article to explore the puzzle of why start-ups are formed as corporations, explained that "the formation of the start-up as a corporation minimized legal and organizational costs," though he characterized these costs as "hardly the most significant" factor in explaining the preference for startups. ${ }^{166}$ Bankman then discussed the costs of a conversion to a corporation upon exit, which were addressed above, and which he admitted were not significant enough to justify initially choosing the corporate form. ${ }^{167}$

\footnotetext{
162. See supra Part III.

163. See infra Subpart IV.A.

164. See infra Subpart IV.A.

165. See infra Subpart IV.C.

166. Bankman, supra note 1 , at 1749.

167. Id. at 1750
} 
Professor Victor Fleischer, in a more extensive discussion, also addressed complexity and compliance concerns. ${ }^{168}$ He noted that incentive compensation in the LLC context, which is typically delivered through profits interests or even as options on membership interests, was more complicated and less familiar to service providers than their corporate analog, stock options. ${ }^{169}$ Fleischer also explained that service providers that are equity owners are not considered employees for tax purposes; meaning that they are required to make estimated tax payments, rather than simply rely on wage withholding as employees are able to do. ${ }^{170} \mathrm{He}$ also described some corporate governance and drafting concerns due to the relative novelty, as well as management flexibility, of LLCs compared to corporations. ${ }^{171}$ Like Bankman, Fleischer also discussed the relatively smoother exit mechanisms for corporations vis-à-vis LLCs. ${ }^{172}$

Professor Calvin Johnson also mentioned complexity issues, although only briefly. ${ }^{173} \mathrm{He}$ noted that start-up lawyers were more familiar with corporations and had, at their fingertips, standardized corporate forms that could be reused time and time again with just a little bit of individualization. ${ }^{174}$

These discussions of compliance and complexity problems were accurate at the time they were written, and for the most part remain so today, though familiarity with the LLC form continues to grow. ${ }^{175}$ However, these discussions missed the real sources of the compliance and complexity problems that make the LLC form particularly unwieldly for Silicon Valley start-ups.

\section{2. $K-1 s, K-1 s$, and More $K-1 s$}

The existing literature has focused on additional complications relating to compensation design, exit structures, and the relative novelty of LLCs. ${ }^{176}$ However, as discussed below, there are other much more significant compliance and complexity problems that have not previously been fully explored: for example, the Form K-1.

Partnerships are required to issue K-1 forms annually to each and every of their partners, regardless of whether the partnership generate profits or losses. ${ }^{177}$ The K-ls inform each partner of the partner's share of the partnership's items of taxable income, gain, deduction, or loss, as well as the tax character of such

\footnotetext{
168. See Fleischer, supra note 1.

169. Id. at 140 ("Organizing as a corporation minimizes legal costs and simplifies employee compensation and exit strategy.").

170. Id. at 169 .

171. Id. at $174-76$

172. Id. at 176 .

173. Johnson, supra note 1 , at 42 .

174. Id. at 60-61 ("Businessmen reuse the same templates and structures, even the same standardized forms, to save legal fees and to avoid the hard work of figuring out new business structures, even when the templates do not fit perfectly.").

175. See sources cited supra note 1 .

176. See supra notes $166-175$.

177. I.R.C. $\$ 702$ (2012).
} 
items (for example, long-term capital gain). ${ }^{178}$ The partners then include information from the K-1 on their own income tax returns. ${ }^{179}$ Accordingly, every taxpayer who is a partner in a partnership must receive a $\mathrm{K}-1$ from each and every partnership in which the taxpayer is an owner, before the taxpayer can properly prepare her own return. ${ }^{180}$

Even in a simple scenario where a taxpayer owns an interest in a small handful of partnerships, this can pose a significant compliance problem. Partners in partnerships must routinely file for extensions of time to file their returns because they have yet to receive all of their K-1s, or because of the possibility that amended $\mathrm{K}-1 \mathrm{~s}$ might be issued. ${ }^{181}$ In cases where upper tier partnerships own interests in lower tier partnerships, the upper tier partnerships cannot file its tax returns and issue its $\mathrm{K}-1 \mathrm{~s}$ to its partners until all of the lower tier partnerships have filed their own tax returns and issued their own K-1s. ${ }^{182}$ It does not take much imagination to see how this can cause serious compliance headaches. In the start-up context, however, these garden variety K-1 problems are made exponentially worse for three main reasons.

First, the number of K-1s that would need to be issued if all start-ups were commonly formed as LLCs would be significant. Many taxable investors in start-ups will own direct (for example, angel investments) or indirect interests, through partnerships (for example, $\mathrm{VC}$ fund investments), in a large number of start-ups. ${ }^{183}$ If many of these start-ups were structured as LLCs, investors (or funds in which they are invested) might have to receive dozens, if not hundreds, of K-1s every year before they can even begin preparing their own tax returns. If a single one of the $\mathrm{K}-1 \mathrm{~s}$ is missing, erroneous, or delayed, it will complicate the investor's tax compliance. For instance, if a single one of those K-1s is issued or amended after the investor has filed its own return, the investor would have to file an amended return incorporating the newly corrected information. ${ }^{184}$

Second, because VC funds are themselves partnerships, there would be cascading K-1 problems. When an LLC start-up is owned in part by a VC fund, the LLC is a lower tier partnership to the upper tier VC partnership. This means that, before the $\mathrm{VC}$ fund could file its own tax return, it would have to first

178. See 2017 Partner's Instructions for Schedule K-I (Form 1065), InTERNAL REVENUE SERV., https://www.irs.gov/pub/irs-pdf/i1065sk1.pdf (last visited Jan. 19, 2019).

179. $I d$.

180. Id.

181. See Arden Dale, Late Tax Returns Common for the Wealthy, WALL ST. J. (Mar. 29, 2013, 9:33 AM), https:/Www.wsj.com/articles/SB10001424127887324000704578390281633525610 (noting the main culprit stopping wealthy taxpayers from filing their return is the "Form K-1")

182. Id.

183. Tax-exempt investors will invest through one or more blockers. Typically, a separate blocker is set up for each investment. Therefore, the blocker would need to receive a $\mathrm{K}-1$ only from one partnership before it could file its own return.

184. See, e.g., Tax Information Center: Correcting Schedule K-I for Your Business, H\&R BLOCK, https:/www.hrblock.com/tax-center/irs/forms/correcting-schedule-k-1-for-your-business/ (last visited Jan. 19, 2019) (answering an individual's question by noting that they must file an amended return if the individual receives a corrected $\mathrm{K}-1$ ). 
receive $\mathrm{K}-1 \mathrm{~s}$ from all of its investee start-ups. Taxable investors in VC funds then must wait to receive $\mathrm{K}-1 \mathrm{~s}$ from all of the $\mathrm{VC}$ funds in which they are invested before the investor can file her own tax returns. Making matters worse, funds of funds are major investors in VC funds. ${ }^{185}$ Funds of funds are themselves structured as partnerships and typically invest in over ten VC funds. ${ }^{186}$ For funds of funds (FOF), there would actually be three tiers of partnerships - the FOF partnership on top, the VC funds in the middle, and the start-up LLCs on the bottom. Any delay or error relating to any one of the start-up LLC's K-1s will have ripple-through repercussions all the way up the chain of partnerships.

Third, the nature of start-up investments is such that the overwhelming majority of start-ups will completely fail. In early stage $\mathrm{VC}$ funds, the failure rate can easily approach or even exceed 90\%, even for funds that are highly successful overall. ${ }^{187}$ Failing and failed start-ups that are LLCs must still issue $\mathrm{K}-1 \mathrm{~s}$, and investors must await those $\mathrm{K}-1 \mathrm{~s}$ before they can properly file their own tax returns. Once it becomes clear that a start-up is failing-usually because it is quickly burning through its cash with the next round of financing becoming more and more unlikely - the start-up's employees will often flee the company, seeking work at another start-up or looking for a "soft landing" at a large company. ${ }^{188}$ Orderly liquidations of failing start-ups are unusual, because a failed start-up often has little in the way of salvageable assets. For instance, the start-up might have technology that simply did not work, never became marketable, or has become obsolete, and it just closes up shop. ${ }^{189}$ In contrast, non-start-up businesses often have property (such as real estate or equipment) that has some salvage value, resulting in a more orderly liquidation process.

Accordingly, when a start-up is dying, it will often be the case that nobody will be around, or have any financial incentive, to assist in properly preparing and filing the start-up's tax returns and K-1s. As a result, it is highly likely that failing start-ups either could not or would not issue timely and accurate K-1s to their investors, complicating tax compliance for them or their own investors.

A taxable investor might respond to this situation by simply filing a tax return without incorporating the investor's share of the failing start-up's tax items, which normally would just include losses. However, that would result in unclaimed losses, and loss flow-through is precisely one of the benefits of

185. See, e.g., Approach, DARwIN VENTURES, http://www.darwinvc.com/approach/ (last visited Jan. 19, 2019).

186. See Funds of Funds Investing, INVESTOPEDIA, https://www.investopedia.com/exam-guide/cfa-level1/alternative-investments/fund-of-funds-investing.asp (last visited Jan. 19, 2019) ("Ordinarily, a fund of funds is structured as a limited partnership.").

187. See Sebastian Quintero, Dissecting Startup Failure Rates by Stage, MEDIUM (Nov. 7, 2017), https:/towardsdatascience.com/dissecting-startup-failure-by-stage-34bb70354a36 (showing an ultimate failure rate of $97 \%$ for seed investees and $89 \%$ for Series A investees).

188. See Marisa Kendall, When Startups Fail, Employees and Customers Are Often Hit Hard, STAR (Oct. 8 , 2016), https://www.thestar.com/business/2016/10/08/when-startups-fail-employees-and-customers-areoften-hit-hard.html (describing the often chaotic failures of startups).

189. See Emma McGowan, The 13 Top Reasons Why Startups Fail, Startups.co (Dec. 14, 2017), https://www.startups.co/articles/why-do-startups-fail. 
choosing the LLC form in the first place. In addition, it remains possible for a failed or failing start-up to actually realize gain. If a failing LLC has outstanding debt, the cancellation of that debt generally triggers income that must be recognized and allocated to its owners. ${ }^{190}$ In that case, simply ignoring the LLC's tax items can result in the investor underpaying taxes.

These compliance problems do not arise when start-ups are formed as corporations. ${ }^{191}$ While investors in partnerships are directly affected tax-wise, for better or for worse, by the activities of their investees, investors in corporations are completely insulated. ${ }^{192}$ Whatever happens "down below" in the investee corporation does not affect the investor's tax return at all. ${ }^{193}$ Of course, if cash or property is distributed by a corporation to the investor, that often results in tax consequences for the investor, such as the realization of dividend income. ${ }^{194}$ But the investor will well know whether and to what extent she received a distribution. Alternately, being a partner in a partnership requires knowledge of what has occurred below at the investee level, regardless of whether any distributions have been made. ${ }^{195}$

\section{The Nature of Early Stage Start-Up Investing}

These compliance problems become even more problematic once the unique nature of early stage start-up investing is considered. The initial choice of entity decision is made very early. ${ }^{196}$ It can be made by the founders even before any outside investment is received.${ }^{197} \mathrm{Or}$, it can be made around the time that seed investors-friends and family or angels-arrive on the scene. ${ }^{198}$ Certainly, by the time a VC fund has actually made a Series A investment, a choice of entity decision has been made.

The problems stemming from $\mathrm{K}-1 \mathrm{~s}$ and high failure rates are significantly exacerbated at the seed or Series A investment stage. Compared to their later stage counterparts, angels and early stage VC funds make smaller dollar

190. See I.R.C. $\$ \S 61(a)(11), 702$ (a) (2012).

191. See William C. Brown, A Primer on Income Tax Compliance for Multistate Pass-Through Entities and Their Owners, 67 TAX LAW. 821, 871 (discussing the greater tax compliance problems of flow-throughs compared to $\mathrm{C}$ corporations).

192. Id. ("Since a $\mathrm{C}$ corporation pays all of the taxes on its business income directly, no reporting of corporate income to shareholders is required by the tax code.").

193. See id.

194. See I.R.C. § 61(a)(7) (including dividends received in gross income)

195. In addition, if a failing corporation realizes cancellation of debt income, income will generally be excluded because the corporation is insolvent. In the corporate context, insolvency is determined at the corporate level, and a failing corporation will typically be insolvent. In contrast, the insolvency exclusion is applied in the partnership context at the partner level, so cancellation of debt income will flow through to the partners even if the partnership itself is insolvent.

196. See Fleischer, supra note 1, at 137 ("A typical start-up is organized as a corporation under state law ....").

197. $I d$.

198. See Goldberg, supra note 1, at 923 (discussing the "angel investors"" preference for corporate form because they view "the tax advantages of LLCs as more theoretical than real"). 
investments in a larger number of start-ups. ${ }^{199}$ In addition, early stage investments are riskier because, by definition, later stage investments have already proven worthy of a subsequent round of investment. ${ }^{200}$ Furthermore, early stage investments that fail often do so most completely, burning through all their cash with little or no salvageable value to show for it. ${ }^{201}$

Each of these factors exacerbates the K-1 compliance problems. The larger the number of investments by a VC fund, the more $\mathrm{K}-1 \mathrm{~s}$ it must receive before the fund can file its own tax return. More failed investments and more complete failures increase the risk that failing and failed start-ups will not issue timely and accurate K-1s.

In addition, while an initial choice of entity decision can in theory be changed, it is generally too costly from a tax perspective to convert from a corporation to a partnership after a start-up begins to show promise. ${ }^{202} \mathrm{~A}$ conversion from a corporation to a partnership requires an actual or constructive liquidation of the corporation, which triggers an immediate double taxation of the corporation's net built-in gain at the time of the conversion. ${ }^{203}$ Accordingly, an initial choice of corporate classification is, for all intents and purposes, permanent, ${ }^{204}$ even though a conversion from a partnership to a corporation is typically easy. ${ }^{205}$

In summary, in early stage VC investment, many small seeds are planted, with the expectation that almost all of them will never bear any fruit at all. ${ }^{206}$ The $\mathrm{K}-1$ compliance issues that would result from this state of affairs push early stage investors to require that their investees are corporations (or convert to corporate status) as a condition of their investment. When a small number of these seeds begin to show promise, such that compliance problems are reduced, it is simply too late to convert them to LLC status.

\section{Transactional Complexity}

Existing commentary has noted that lawyers who deal with start-up investment, whether representing founders or investors, are more familiar with corporate documentation, such as articles of incorporation, bylaws, and

\footnotetext{
199. See supra Subpart II.B.

200. See Morse \& Allen, supra note 40 , at 358.

201. See id. at 377.

202. See LEVIN \& RoCAP, supra note 8, If 302.2.2, at 3-38 (noting that a partnership cannot be party to a $\$ 368$ reorganization and discussing why the conversion would trigger an unsavory taxable gain for most owners).

203. See generally I.R.S. Priv. Ltr. Rul. 97-01-029 (Jan. 3, 1997) (noting that a state law merger of a C corporation into an LLC is a taxable liquidation under I.R.C. $\$ 331$ and will not qualify for nonrecognition treatment).

204. See supra text accompanying note 202.

205. See generally Rev. Rul. $84-111,1984-2$ C.B. 88 (noting that in most cases, $\$ 351$ would allow for nonrecognition of the built-in gain within the partnership at the time of conversion).

206. See Morse \& Allen, supra note 40 , at 376
} 
shareholders' agreements, than with their LLC counterparts. ${ }^{207}$ Previous commentators have also described the less mature body of state law regarding LLCs. ${ }^{208}$ Commentators have also discussed the additional flexibility afforded to LLC originators. ${ }^{209}$ LLC statutes include some default rules which can be amended, where their corporate counterpart has mandatory rules. ${ }^{210}$ For example, while corporations must be managed by a board of directors, LLCs may choose to be managed directly by members or by a board of managers. ${ }^{211}$

All of these factors complicate, slow down, and increase the costs of the investment process to some extent. The use of less familiar legal forms requires more drafting and reviewing. ${ }^{212}$ The less mature the body of law, the greater the degree of legal uncertainty. Greater legal uncertainty might require more careful, and therefore more time-consuming, drafting and reviewing. ${ }^{213}$ And, to the extent that additional legal uncertainty remains, that itself is an additional cost. ${ }^{214}$ Greater legal flexibility also generally requires more care and thought in drafting and reviewing documents.

In short, the corporate form is much more "cookie-cutter" than the LLC form. ${ }^{215}$ At the earliest stage of investment-seed rounds and the Series A round-cookie-cutter structures are particularly desirable for two reasons. First, they must beat any competitors to market. ${ }^{216}$ Second, the staging of investment rounds means that early stage start-ups are in a race to "prove it or lose it."217 They must prove their worthiness to receive the next round of financing before they burn through their existing cash; otherwise, they will fail. In this context, slowing the process down because of legal technicalities and wasting precious early stage financing on legal fees are complete anathemas. ${ }^{218}$

\footnotetext{
207. See, e.g., Fleischer, supra note 1, at 167 ("It has been easier, historically, to create and run a start-up organized as a corporation rather than as a partnership or LLC.").

208. See LEVIN \& ROCAP, supra note 8, II 303.1.4, at 3-55 ("Because most LLC statutes are recent, there is little or no judicial guidance [which] may create uncertainty regarding the rights and obligations of and among LLC members, managers, and officers.").

209. Fleischer, supra note 1, at 173 (noting that the flexibility in LLC agreements "brings uncertainty" as to "whether the agreements will be enforceable in court").

210. For example, there is great "flexibility with respect to management of the company, the rights and obligations from one member to another, and disclosure obligations" and the ability for "members to waive fiduciary duties." Id.

211. Id.

212. Id. at 174 (discussing how "the start-up's lawyers have to draft appropriate protections in the LLC operating agreement" for the uncertainty discussed above).

213. See id. at 173.

214. Id. at 175 (noting that "the uncertainty of the LLC form increases legal costs").

215. See Crouch, supra note 25 , at 210-7 (describing the "cookie cutter" approach of organizing all new startups as C corporations).

216. Ilya Pozin, Speed Is Key to Startup Success (Here's How to Move Fast), INC. (Aug. 31, 2016), https:/www.inc.com/ilya-pozin/speed-is-key-to-startup-success-heres-how-to-move-fast.html.

217. Venture Round, WIKIPEDIA, https://en.wikipedia.org/wiki/Venture_round (last updated Oct. 19, 2018).

218. Morse \& Allen, supra note 40 , at 360 (describing a model that shows firms who do not engage in tax planning are rational because the tax incentives are "unlikely to motivate the desired innovative or entrepreneurial behavior" which would lead to firm success).
} 
Furthermore, recall that generally about $90 \%$ of early stage start-ups will completely fail and that early stage investors plant lots of small seeds. ${ }^{219}$ Because of these factors, there is a sense that wasting time and money on perfecting a legal structure that will ultimately be beneficial only in the unlikely case that the start-up succeeds is unwise. An analogy is planning on how to spend lottery winnings before the numbers are drawn. In addition, the thought may be that, if the company becomes successful, things can get cleaned up then. However, as discussed above, the choice of the corporate form is in fact permanent. ${ }^{220}$

While all of this is true to some extent, these previously discussed costs are surely diminishing over time. LLCs have been around now for over forty years, so there is far more familiarity than when Bankman first addressed the choiceof-entity puzzle in $1994 .^{221}$ Legal uncertainty has been reduced as case law regarding LLCs has developed. Technological improvements probably cut both ways. On the one hand, legal databases and software make it easier to move away from cookie-cutter approaches. On the other, technological advancements also have made the start-up race even more frenetic.

While the existing commentary correctly recognizes that additional transactional complexity plays a role, ${ }^{222}$ it has missed the real source of these complications. The real problems are not the result of relative unfamiliarity or legal uncertainty, but rather because the nature of flow-through taxation is such that LLCs simply require greater technical expertise as well as more careful attention. ${ }^{223}$ While a shareholder's taxes are not affected by whatever activity goes on down below in the corporation, an LLC member's taxes are always affected and potentially in very significant ways. ${ }^{224}$

Well-drafted LLC agreements must include provisions to deal with this vicarious taxation. The most obvious example is the minimum tax distribution provision. ${ }^{225}$ LLC agreements often include such a provision to assure investors they will have sufficient liquidity to pay any taxes resulting from flow-through

\footnotetext{
219. See Funds of Funds Investing, supra note 187.

220. See supra Subpart I.B.

221. See generally Bankman, supra note 1.

222. See, e.g., Fleischer, supra note 1 , at 171-73.

223. See id. at 172 ("Drafting an option on a partnership interest is a complex task and is normally much more difficult than drafting an option on a share of common stock in the corporate context. It requires an understanding of the parties' economic deal, the partnership's allocation, distribution and capital account mechanics and the interaction of those mechanics with the purchase of a partnership interest on exercise of the option (including, e.g., the initial capital account to be given to [the service partner] on exercise of the option and the impact of writing up (or not writing up) capital accounts on option exercise)." (alteration in original) (quoting William R. Welke \& Olga A. Loy, Compensating the Service Partner with Partnership Equity: Code $\$ 83$ and Other Issues, 79 TAXES 94, 112-13 (2001))).

224. See supra Subpart IV.A.2.

225. See generally Bahar A. Schippel, Boilerplate Tax Distribution Provisions Can Get You into Hot Water, 32 TAX MGMT. REAL EST. J. 46 (2016) (discussing varying tax distribution schemes).
} 
income. ${ }^{226}$ These provisions must then be integrated with the ordinary distribution waterfall, which can be quite tricky. On the other hand, there is no need for any comparable provision in the corporate context because shareholders will have tax consequences only if and when distributions are received, so the ordinary distribution waterfall is all there is. ${ }^{227}$

In addition, the technical mechanics of flow-through taxation are notoriously complicated. ${ }^{228}$ Flow-through taxation is a more conceptually complex scheme and also one that is uniquely susceptible to taxpayer abuse. ${ }^{229}$ On the other hand, the classical corporate tax system is relatively simple. These differences mean that LLC legal documentation is far more complicated than their corporate counterpart. While a shareholder's agreement may have little, if any, tax language in it, a well-drafted LLC agreement will be inundated with tax jargon that is understandable, if at all, only by lawyers who are expert in partnership $\operatorname{tax}^{230}$ The agreement will include tax provisions addressing "qualified income offsets," "excess nonrecourse liabilities," and "minimum gain chargebacks. ${ }^{231}$ If a start-up is structured as an LLC, this state of affairs leaves a business lawyer representing start-ups, their founders, or their investors with two unattractive options. The lawyer can involve a tax lawyer in the matter, which will increase the legal costs and potentially delay the transaction. Or, the lawyer can recommend that his or her client sign an LLC agreement that the lawyer does not completely understand and could not fully explain to the client if asked. In the fast-paced, low-cost, plant-many-seeds, high-risk context of early stage start-up investment, involving another lawyer on each side of the table is an extremely unattractive option. Initial corporate classification avoids this Sophie's choice entirely.

\section{Ex Ante Picking and Choosing}

The discussion above has assumed an "all or nothing" approach to entity selection by start-ups. If all start-up investments held, directly or indirectly, by an investor were LLCs, this would cause overwhelming compliance and complexity issues. But if one or two or three were LLCs, it would probably be

226. See generally JACK S. Levin \& Donald E. RoCaP, Structuring Venture Capital, Private Equity, and Entrepreneurial Transactions I[ 1003.5, at 10-16 (Martin D. Ginsburg \& Russell S. Light eds., 2015).

227. Similarly, because of flow-through taxation, tax-exempt and foreign investors necessitate the formation of a blocker. This complicates the ownership structure and requires the drafting of another set of organizational documents.

228. See Foxman v. Comm'r, 41 T.C. 535,551 n.9 (1964) ("The distressingly complex and confusing nature of the provisions of subchapter $\mathrm{K}$ present a formidable obstacle to the comprehension of these provisions without the expenditure of a disproportionate amount of time and effort even by one who is sophisticated in tax matters with many years of experience in the tax field.").

229. See id.

230. See generally Steven R. Schneider \& Brian J. O'Connor, Partnership and LLC Agreements: Learning to Read and Write Again, 125 TAX NOTES 1323 (2009) (explaining the various tax terms found in partnership agreements).

231. See id. 
manageable. The obvious problem is that the investor would have to select ex ante which few investments would be held as LLCs. With twenty-twenty foresight, investors would select their winners to be LLCs. This would allow them to get the SUB premium on the successful exit. It would also make moot the compliance problems associated with failing LLCs.

Of course, if the investor had twenty-twenty foresight, the investor would only invest in winners! In the real world, early stage start-up investors simply cannot tell which investments will succeed. ${ }^{232}$

\section{B. OTHER COMPLICATIONS}

\section{State Tax Compliance}

Another complication from flow-through taxation relates to state income taxation. If a flow-through engages in business activity within multiple states that have an income tax, the entity has to file a tax return in each and every one of those states. ${ }^{233}$ While corporations have the same general filing obligation, the compliance burdens on flow-throughs (and their owners) are higher for two reasons.

First, as with the federal income tax, state income taxation of partnerships is simply more complicated. For example, flow-throughs need to sort through withholding requirements for its nonresident owners. ${ }^{234}$ Some states require an entity to file a "composite" income tax return "on behalf of its owners who are not residents of the state. ${ }^{\prime 235}$ Furthermore, many states have separate state specific K-1s that the entities must file with the partners and state taxing agency. ${ }^{236}$

Second, owners of flow-throughs are generally required to file their own income tax returns in each and every state in which the flow-through does business. ${ }^{237}$ While some states provide for composite returns, which alleviate the filing burdens on owners, not all do. ${ }^{238}$ In contrast, owners of corporations have

232. See Fleischer, supra note 1, at 142 (explaining that "[e]ntrepreneurs are optimists" and how "the gambler's mentality of Silicon Valley would appear to be a plausible explanation for why start-ups are organized as corporations" while "[a] behavioral law and economics approach would suggest that entrepreneurs and venture capitalists are foolishly optimistic and should pay more attention to losses").

233. See William C. Brown, A Primer on Income Tax Compliance for Multistate Pass-Through Entities and Their Owners, 67 TAX LAW. 821, 861-64 (2014).

234. Id. at $861-69$.

235. Id. at 864 .

236. Id. at 872 n.271 ("California, Illinois, Iowa, Kentucky, Missouri, New Jersey, New York, Pennsylvania, and Virginia all require the preparation and filing of state specific Schedule K-1s.").

237. See BARTLETT, supra note $21, \S 3.5 \mathrm{~A}(\mathrm{C})(4)$ ("If a PE/VC Fund invests in an unincorporated portfolio company that conducts business in many states (presumably any business activities of that company in foreign countries will be conducted through foreign corporations), its investors either will need to be included as part of composite returns filed by the partnership or separately incur the expense and challenge of having to file their own income tax returns in those states. Some states, however, do not give the partners this option; instead, they require the partnership to withhold and pay state income taxes on each non-resident partner's share of the partnership's income attributable to that state.").

238. $I d$. 
no corresponding state income tax filing obligations resulting from their stock ownership. ${ }^{239}$

\section{Equity Compensation Design}

Equity compensation (such as stock options) is extremely common in the start-up context, because of its perceived incentive effects and because it preserves cash. ${ }^{240}$ Equity compensation paid by corporations is far simpler and easier to understand than that paid by LLCs. ${ }^{241}$

A service provider of a start-up corporation will be classified as an employee and will typically receive stock options. ${ }^{242}$ The employee will receive W-2 wages, and the employer will pay to the IRS income tax withholding and employment taxes on both regular salary and income from the exercise of stock options. ${ }^{243}$

Matters are far more complicated in the LLC setting. An owner of LLC equity cannot be an employee. ${ }^{244}$ This means that any "salary" received by an owner is not treated as W-2 wages, but instead is self-employment income. ${ }^{245}$ Accordingly, there will be no withholding by the LLC, and the service provider will have to make quarterly estimated tax payments. In addition, instead of receiving stock options, the service provider will receive so-called "profits interests," which are economically very similar to stock options but are somewhat more complicated and are far less common in the start-up community. ${ }^{246}$ The bottom line is that it is simpler and more common to issue and receive $\mathrm{W}-2$ wages and stock options than to issue and receive selfemployment income and profits interests.

\section{Practical Difficulties in Fetching the SUB Premium}

Recall that the three general benefits of flow-through taxation are (1) single taxation of income, (2) flow-through (rather than trapping) of losses, and (3) the

\footnotetext{
239. $I d$.

240. See Fleischer, supra note 1 , at 167 ("Clompensation issues make the $\mathrm{C}$ corp structure more attractive than the pass-through structure.").

241. Id.

242. Founders of the company will generally receive "founder's stock," which is vested or unvested shares of stock (as opposed to options). Employees hired after founding generally receive stock options. The reason for this difference is that, at the founding of the company, the shares are worth nearly nothing, so the founders can pay full fair market value for their shares (for example, a penny a share). As the company matures, the stock value grows and, if an employee receives shares by paying less than full value, the employee realizes immediate ordinary income. Giving stock options, with a fair market value exercise price, avoids this problem. See generally Polsky \& Hellwig, supra note 71.

243. See Fleischer, supra note 1 , at 168 .

244. Id. at 169 .

245. See id. at 170 ("[E]mployees who are treated as partners would have to pay an additional selfemployment tax on salary ....").

246. While in theory the service provider can receive "unit options," options to buy units of the LLC, the tax treatment of the exercise of partnership options is unsettled and can result in onerous and counterintuitive consequences for the non-exercising LLC owners. For these reasons, tax professionals generally strongly prefer profits interests, which are economically very similar to partnership options, over unit options.
} 
ability to deliver a SUB to a buyer on exit. ${ }^{247}$ In the start-up context, the single taxation of income is often irrelevant, as profits are not typically realized before exit. And the loss flow-through benefit, while not completely irrelevant, can be significantly blunted by the presence of tax-indifferent investors, the passive activity loss limitations applicable to U.S. individuals, the scarcity of corporate investment, and the allocation of only net income (and not losses) to individual fund managers with respect to their carried interest. ${ }^{248}$ In contrast, the third benefit - the ability to deliver a SUB to the buyer and fetch a premium purchase price-retains much of its apparent value even in the unique start-up context. ${ }^{249}$ While traditional tax-indifferent investors will generally not benefit from this (because they are forced to invest through blockers and exit by selling blocker stock), all other investors should receive a significant premium purchase on exit.

However, delivering a SUB is only beneficial to sellers to the extent that buyers are willing to pay a premium for it. The expected value of the SUB can be substantial. As previously mentioned, under reasonable assumptions, a premium of approximately $20 \%$, relative to a purchase price based on a carryover basis (COB), can be expected. Nevertheless, the conventional wisdom is that the public stock market severely undervalues SUBs (as well as tax assets more generally), and in fact may completely ignore them, in valuing a company. ${ }^{250}$ Because the desired exit for successful start-ups is either to go public or to be acquired by a public company, undervaluation of the SUB by the public markets would dramatically reduce or perhaps completely eliminate the most significant tax-related benefit to structuring start-ups as LLCs.

\section{The Theoretical Advantage of Delivering a SUB}

When an acquirer buys a successful business, it will generally prefer to take the business's assets (including intangible assets like goodwill and going concern value) with a SUB rather than the lower COB. ${ }^{251}$ The higher the basis in the assets, the greater the buyer's future depreciation and amortization deductions. ${ }^{252}$ In addition, gains on the sales of the purchased assets (such as inventory) will be lower, while losses will be greater. ${ }^{253}$ All of these consequences serve to lower the buyer's future tax burden, resulting in more after-tax cash in its pockets. ${ }^{254}$ As a result, the buyer should theoretically be willing to pay more for the business with a SUB than without it.

\footnotetext{
247. See supra Subpart I.B. (explaining single taxation of income and loss flow-through); infra note 108 and accompanying text (noting the SUB delivery).

248. See supra Part III.

249. See infra Subpart IV.C.1.

250. See Polsky \& Rosenzweig, supra note 2 , at 429 \& n.62.

251. See Michael L. Schler, Basic Tax Issues in Acquisition Transactions, 116 PeNn ST. L. Rev. 879, 887-

88 (2012) (explaining the benefit to the buyer of a SUB).

252. See id. at 887.

253. See id.

254. See id. (explaining that the present value tax savings of a SUB is approximately $20 \%$ of the SUB, using traditional assumptions).
} 
The theoretical premium equals the amount of expected future tax reductions discounted to present value. ${ }^{255}$ This value depends on a host of factors, including future marginal tax rates, the time and manner in which the buyer generates future annual taxable income, the allocation of the purchase price among various types of assets, and the appropriate discount rate. ${ }^{256}$ The higher the marginal tax rates, the greater the tax savings, and vice versa. Marginal rates can be affected by tax legislation or by changes in the profitability of the buyer. ${ }^{257} \mathrm{~A}$ long delay in reaching profitability reduces the present value of future tax savings. Allocation of the purchase price affects the SUB's present value because the greater the allocations to assets whose costs are recovered quickly (through, for example, quick sales or fast depreciation schedules), the greater the tax savings in the early years. And the discount rate is critical because, while some tax reduction from a SUB may occur shortly after the purchase, a significant portion of it may be recognized only years down the road. This is because, for highly successful businesses, like a start-up that is going public, the vast majority of the purchase price will be allocated to goodwill, which is depreciated ratably over fifteen years. ${ }^{258}$

Some reasonable assumptions, at least for purposes of merely ballparking the theoretical value of a SUB, are that (1) the buyer's future marginal tax rate is equal to the combined federal and state corporate rate of $40 \%$ (consistent with historical rates); (2) all of the SUB is allocated to goodwill; and (3) the appropriate discount rate is $10 \% .{ }^{259}$ Under these assumptions, the theoretical SUB premium is approximately $20 \%$ of the step up. ${ }^{260}$ This means that if a buyer was willing to pay $\$ 1$ billion for a business with a COB of zero, the buyer should be willing to pay roughly $\$ 1.2$ billion if it gets a SUB. Using the new corporate tax rate of $21 \%$ (down dramatically from $35 \%$ ) and assuming no state corporate tax, ${ }^{261}$ but holding all other assumptions constant, would yield a SUB premium of $12 \%$. Because this Article is analyzing historical choice of entity decisionmaking, it will use the estimated $20 \%$ premium that results from the application of the historical $35 \%$ corporate rate. Note also that, technically, the premium is based on the amount of the step up, not the overall purchase price. But in the start-up context, exited companies will typically not have significant basis, because they will have used most of their investment proceeds on deductible

255. See Polsky \& Rosenzweig, supra note 2 , at 420

256. See id.; see also Schler, supra note 251, at 887 (approximating the value of SUB based on certain assumptions).

257. See I.R.C. $\S 1$ (Supp. V 2017) (providing new graduated tax rates).

258. See id. \$ 197; see also Schler, supra note 251 , at 887 ("In practice, much of the step up is usually allocable to intangible assets of Target that have a very low tax basis to Target and for which Acquiring is permitted to amortize the new basis over 15 years.").

259. This may seem high, but given the risky nature of the future tax benefits (as a result of doubts about profitability or changes in corporate tax rates) it is not unreasonable. A lower discount rate would increase the SUB premium.

260. See Schler, supra note 251 , at 887 .

261. I.R.C. $\$ 11$ (b) (Supp. V 2017) (after passage of the Tax and Job Cuts Act of 2017); I.R.C. \& 11(b) (Supp. IV 2016) (before passage of the Act). 
expenses, such as research and development expenses and employee compensation. ${ }^{262}$ Thus, for ease of exposition, this Article assumes a $20 \%$ SUB premium relative to an otherwise equivalent $\mathrm{COB}$ purchase price.

Delivering a SUB is extremely easy for businesses that are organized as LLCs or other tax partnerships. The partnership can simply sell their assets to the buyer. Or the buyer can buy all of the outstanding LLC interests. Because a single member LLC is disregarded for income tax purposes, the tax law treats such a transaction as a sale of all of the assets to the buyer. ${ }^{263}$ Critically, in either case, gains recognized from the (actual or deemed) sale of the assets are taxed once and only once at the owner level, as a result of flow-through taxation. ${ }^{264}$ There is no second level of tax. In addition, because much of the overall gain generated by the sales of highly successful start-ups is attributable to goodwill, which is a capital asset, the vast majority of the gain is typically taxed at preferential capital gains rates. ${ }^{265}$

For these reasons, it is easy for LLC owners to deliver to the buyer its desired SUB. This is not the case in the corporate context, because of double taxation. A sale of corporate assets, which would result in the buyer receiving a SUB, would result in immediate tax at the corporate level and then, when the sales proceeds are distributed to the shareholders, another tax at the shareholder level. ${ }^{266}$ Even with the SUB premium, this immediate double taxation would commonly leave the shareholders with less after-tax cash than if they had sold their stock. In such a stock sale, the buyer would receive only a COB in the business's assets and therefore would not pay the SUB premium. But by avoiding the double tax, the shareholders would still be better off even while foregoing the SUB premium.

To illustrate, consider a corporation owned by a single individual. The corporation's stock is worth $\$ 100$, the corporation's only asset is goodwill with a zero basis, and the shareholder's basis is zero. A sale of the stock for $\$ 100$ would leave the shareholder with $\$ 80$, assuming a $20 \%$ capital gains rate. If instead the transaction was structured as a sale of assets, the buyer would be

262. See I.R.C. $\$ 174$ (a) (2012) (allowing deduction of research and development expenditures); I.R.C $\$ 162(\mathrm{a})(1)$ (allowing deduction of employee compensation).

263. See Treas. Reg. $\$ 301.7701-3$ (b)(1)(ii) (2018) (stating that a domestic eligible entity with one owner is treated as a disregarded entity under the default rule); Rev. Rul. 99-6, 1999-6 I.R.B. (concluding that a purchase of all of an LLC's interests by a single purchaser is treated as an asset purchase for tax purposes). If there are multiple buyers, or if the buyer wishes to buy only a portion of the outstanding LLC interests, the SUB can be delivered if the LLC makes a $\$ 754$ election.

264. See I.R.C. $\$ 701$ (Supp. V 2017).

265. Better Beverages, Inc. v. United States, 619 F.2d 424, 425 n.2 (5th Cir. 1980) ("[G]oodwill is a capital asset ... ."); Dixie Fin. Co. v. United States, 474 F.2d 501, 506 n.5 (5th Cir. 1973) (noting that "[g]oodwill is a capital asset, and amounts received therefor in excess of the seller's basis are treated as capital gains," but that they represent a nonamortizable capital investment resulting in no corresponding deduction for the purchaser); Comm'r v. Killian, 314 F.2d 852, 855 (5th Cir. 1963) ("It is settled that goodwill, as a distinct property right, is a capital asset under the tax laws."); Michaels v. Comm'r, 12 T.C. 17 (1949) ("We entertain no doubt that good will and such related items as customers' lists are capital assets.").

266. See Polsky \& Rosenzweig, supra note 2, at 421-22. 
willing to pay $\$ 120$ because of the SUB premium. The corporation would then pay $\$ 42$ in corporate tax ( $\$ 120 \times .35$ ), leaving $\$ 78$ to be distributed ${ }^{267}$ The $\$ 78$ distribution would leave the shareholder with $\$ 62.40$ of cash $(\$ 78 \times(1-.2)$ ), which is $\$ 17.60$ less than when the shareholder had sold stock. Thus, the shareholder would sell stock. Had the corporation been initially formed as an LLC, the buyer would buy assets and leave the owner of the LLC with $\$ 96$ after $\operatorname{tax}(\$ 120-\$ 24$ capital gains tax $)$.

Stepping back from the technicalities, these results make perfect sense. A purchase of corporate assets reduces the buyer's future corporate tax liabilities with respect to the amount of built-in gain in the acquired assets. ${ }^{268}$ But at the same time, an asset sale increases the seller's current corporate tax liabilities with respect to the same amount of built-in gain. Because of the time-value of money, this tradeoff of less future taxes for greater current taxes in the same amount is not desirable unless the buyer's future corporate tax rates are significantly greater than the seller's current corporate tax rate.

\section{Discussion of SUB Delivery in the Existing Literature}

The ability of LLCs to deliver SUBs is quite a big deal. A purchase price premium of $20 \%$ is significant. And the premiums can be staggering in absolute terms. For corporate start-ups that go public, the theoretical value of the SUB can easily be in the hundreds of millions, if not billions, of dollars. Furthermore, in contrast to the tax benefit of loss flow-throughs, there are no restrictions or limitations, such as the passive activity rules, that would impair this benefit, and it is fully available to carried interest holders and super tax-exempts.

Despite its significance, the academic literature on start-up choice-of-entity has, with one exception, completely ignored the theoretical SUB premium. Only Fleischer even mentioned it, but only briefly near the very end of his article. ${ }^{269}$ He correctly noted that "an asset sale from a partnership has the distinct advantage of giving the buyer a step-up in basis in the target's assets without incurring an extra layer of tax," explaining the mechanics of the SUB on the second-to last paragraph in a fifty-page article. ${ }^{270}$

\section{Delivery of the SUB in Practice}

The theoretical value of SUBs is indisputable. SUBs are expected to lower future tax liabilities, leaving the business with greater after-tax cash than in an otherwise identical COB transaction. Of course, it is possible that the business might not generate sufficient profits to utilize the SUBs or even that the corporate tax could be drastically reduced or even eliminated entirely through

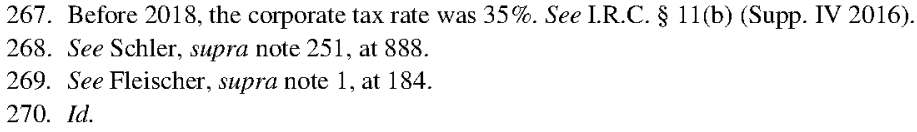


legislation. ${ }^{271}$ In fact, the top statutory corporate rate was recently reduced dramatically. ${ }^{272}$ But these risks only go to the amount of expected value, not to the question of whether there is any such value. SUBs would have zero expected value only if it was absolutely certain that the business will never generate profits or that the corporate tax would immediately be eliminated in its entirety. However, when start-ups go public or are acquired by public companies, there is surely the expectation that they will eventually become profitable, and the corporate income tax has been in place for over 100 years. ${ }^{273}$ Thus, it is safe to say that SUBs of start-ups that are exited have significant theoretical value.

Nevertheless, the conventional wisdom is that the public stock market routinely disregards SUBs (or places an extremely low value on them) in valuing businesses despite their theoretical value. ${ }^{274}$ The traditional explanation for this is based on two factors. First, the public market, in valuing businesses, appears to place great weight on metrics that are based on financial accounting earnings, such as EBIT or EBITDA. ${ }^{275}$ Second, these accounting metrics do not reflect the tax benefits resulting from a SUB. ${ }^{276}$ The result is that the earnings, EBIT, and EBITDA of an acquired business will be the same regardless of whether the acquirer gets a SUB or COB. ${ }^{277}$ Accordingly, a valuation of the business based on a multiple of these metrics will yield the same value in either case.

An alternative explanation for the stock market's tendency to discount SUBs is that the future tax benefits are in fact rationally significantly discounted. ${ }^{278}$ Rational discounting may be the product of significant concerns about future profitability, future corporate tax rates (or even the future viability of the corporate tax), and the availability of tax avoidance opportunities. ${ }^{279}$ All of these concerns would reduce expected future marginal effective tax rates, which in turn reduces the value of SUBs. ${ }^{280}$

Regardless of the reason, the widely held view is that the public market does not pay very much for SUBs. ${ }^{281}$ As evidence, commentators point to the fact that traditionally when LLCs went public, they simply incorporated on a

271. For example, if the federal income tax were transformed into a consumption tax, the corporate income tax would be eliminated.

272. Compare I.R.C. $\$ 11$ (b) (Supp. V 2017) (21\% corporate rate), with I.R.C. $\$ 11$ (b) (Supp. IV 2016) (35\% corporate rate). The new rate will be in effect on January 1, 2018.

273. See Jack Taylor, Corporation Income Tax Brackets and Rates, 1909-2002, INTERNAL REVENUE SERV., https://www.irs.gov/pub/irs-soi/02corate.pdf (last visited Jan. 19, 2019) (showing corporate tax rates from 1909 through 2002).

274. See Polsky \& Rosenzweig, supra note 2, at 429-32.

275. See generally Lawrence M. Benveniste \& Paul A. Spindt, How Investment Bankers Determine the Offer Price and Allocation of New Issues, 24 J. FIn. ECON. 343 (1989); Moonchul Kim \& Jay R. Ritter, Valuing IPOs, 53 J. FIN. ECON. 409 (1999).

276. See Polsky \& Rosenzweig, supra note 2 , at 429-32.

277. See id.

278. See id. at $432-33$.

279. See id.

280. See id.

281. See id. 
tax-free basis, thereby relinquishing any opportunity to achieve an SUB. ${ }^{282}$ In other words, they effectively gave away the SUB for free. Commentators also point to the increasingly popularity of tax receivable agreements (TRAs) in going-public transactions. ${ }^{283}$ TRAs allocate most (usually $85 \%$ ) of the tax benefit resulting from a SUB or other tax attribute back to the sellers if and when the tax attribute actually reduces the buyer's future taxes. ${ }^{284}$ In essence, TRAs leave the tax attribute (technically, $85 \%$ of it) back with the sellers. The logical implication of a TRA is that the sellers value the tax attribute significantly more than the buyer. Absent such a pricing disparity, the parties would simply price the tax attribute into the deal and avoid the administrative problems of carving it out. ${ }^{285}$ The annual computation, payment, and tax and financial reporting of TRA payments is administratively burdensome, TRA rights can result in some messy conflicts of interest, and the mere existence of a TRA complicates the initial public offering ("IPO") process. ${ }^{286}$ Thus, the pricing disparity must be significant enough to justify these significant complications.

The conventional wisdom surely helps explain the traditional preference for corporate classification by start-ups. The desired exit for start-ups is usually to either go public or to be sold to a public company. ${ }^{287}$ In either case, the effective buyer is the public market. If the buyer is not going to pay a premium for a SUB, the only significant benefit of being an LLC is eliminated. ${ }^{288}$ The best evidence of this futility is that, until only recently, LLCs that went public would convert on a tax-free basis to a corporation thereby relinquishing the prospect of a SUB. ${ }^{289}$ These LLCs went through all the complications of the LLC form from their inception all the way up to the IPO, but ultimately got nothing for their troubles.

Compare, for example, two start-ups that go public - one that was formed as an LLC and the other as a corporation. The one that was formed as an LLC is converted tax-free on the eve of its IPO to a corporation (as was historically common), and it therefore delivers a COB. The one that was formed as a corporation uses the corporation as the public vehicle, automatically delivering a COB. They each end up in mostly the same place. The differences are (1) the LLC's pre-IPO losses flowed through to its owners while the corporation's losses were trapped, but as discussed above this benefit is much smaller than it appears due to the presence of tax-indifferent ownership and the passive activity rules, (2) the LLC resulted in additional administrative, transactional, and compliance complexity (including the utilization of a blocker corporation in the

\footnotetext{
282. See generally Gladriel Shobe, Supercharged IPOs and the Up-C, 88 U. COLO. L. REV. 913 (2017).

283. See Victor Fleischer, Taxing Founders' Stock, 59 UCLA L. Rev. 60, 90-91 (2011).

284. See Polsky \& Rosenzweig, supra note 2, at 452-56.

285. See id. at 454 .

286. See id. at 457 (noting the costs of negotiating, drafting, and administering a TRA).

287. See supra Subpart II.B

288. Recall that single taxation of ordinary course income and flow-through of losses are not significant benefits in the start-up context.

289. See generally Victor Fleischer \& Nancy Staudt, The Supercharged IPO, 67 VAND. L. REV. 307 (2014).
} 
ownership structure), and (3) the LLC required a restructuring on the eve of the IPO. All things considered, it is not surprising that corporate classification was the preferred approach for start-ups.

\section{SUMMARY}

The existing academic literature on start-up entity choice has underappreciated two factors that historically encouraged the use of the corporate form. Tax compliance issues and the additional transactional complexity associated with LLCs were especially problematic. In the early stage start-up context, numerous investors make many small investments, time is of the essence, legal costs are disfavored, and the vast majority of companies end up completely worthless. These factors make the extra administrative burdens of LLCs far more problematic than prior commentators realized.

At the same time, the actual benefits of LLCs are smaller than they might appear. The ability to fetch a premium purchase price for delivering a SUB should in theory be quite significant. Furthermore, the premium should be available to a broad swath of start-up investors. However, the conventional wisdom is that public companies will not pay much, if anything, for a SUB. Because the desired exit of a start-up is to become, or be acquired by, a public company, the ability to actually fetch a premium for delivering SUB is more theoretical than real.

Thus, upon close reflection, the traditional costs of using an LLC turn out to be higher than previously understood, while what appears to be the most significant benefit is in fact much smaller or even nonexistent.

\section{CONCLUSION}

The historical preference of start-ups for corporations over LLCs has puzzled observers for over twenty-five years. Despite gallant efforts by prior commentators, no one has yet adequately explained the phenomenon. This Article attempts to do so by identifying two significant practical issues, one of which makes the LLC form more burdensome than previously appreciated and the other that makes a theoretical benefit of using LLCs impossible to fully monetize. Due to the unique nature of early stage start-up investment, tax compliance issues and transactional complexity associated with LLCs are particularly problematic. And, because of valuation idiosyncrasies by the public market, SUB premiums, which should be generated in sales by LLC owners, are practically unavailable in typical start-up exits. Combined, these two factors explain the puzzle.

While this explains the historical tendency to prefer the corporate form, recent legislative developments and structural innovations will dramatically affect the choice of entity analysis going forward. An exclusion for qualified small business stock, which historically was immaterial but was recently significantly expanded, can exempt some of the gain recognized by U.S. 
individual investors in start-ups from capital gains tax. ${ }^{290}$ New corporate income tax rates, effective for the first time in January 2018, are vastly reduced from a top marginal rate of $35 \%$ to a flat rate of $21 \% .{ }^{291}$ These factors push in favor of corporate classification.

On the other hand, a relatively new legal innovation, the Up-C IPO structure, pushes in favor of partnership classification. ${ }^{292}$ In an Up-C IPO, the potential for a SUB is preserved. Historically, when LLCs went public, the SUB was essentially given away for free because of the perception that public markets do not value it. To solve the valuation pricing problem described above, Up-C IPOs include tax receivable agreements, which allocate the ultimate benefits of the preserved SUBs to the LLC owners. ${ }^{293}$ While Up-C IPOs are more complex than traditional IPOs of LLCs, market acceptance of the structure has been growing exponentially. ${ }^{294}$ The end result is that LLC owners can now much more easily monetize the benefit of creating SUBs, which pushes in favor of using LLCs over corporations.

In addition, the new pass-through deduction, which generally excludes $20 \%$ of LLC income recognized by a U.S. individual investor from tax and which became effective on January 1, 2018, also pushes in favor of LLCs. ${ }^{295}$ Because of these four recent developments - the expanded exclusion for qualified small business stock, the new corporate tax rate, the market acceptance of Up-Cs, and the pass-through deduction-the ground has shifted considerably regarding choice-of-entity. Nevertheless, the pragmatic problems that would stem from widespread LLC adoption in the VC world remain and will likely remain insurmountable, regardless of these developments.

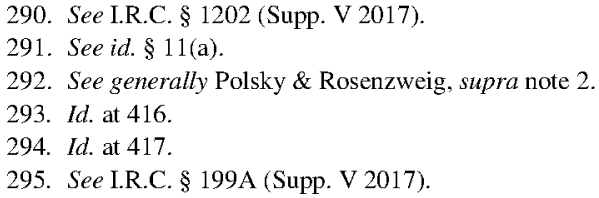

